\title{
Neurotrophin Responsiveness of Sympathetic Neurons Is Regulated by Rapid Mobilization of the p75 Receptor to the Cell Surface through TrkA Activation of Arf6
}

\author{
다. Edward Hickman, ${ }^{\star}$ Emily M. Stanley, ${ }^{\star}$ and ${ }^{\circledR B}$ Bruce D. Carter \\ Department of Biochemistry and Vanderbilt Brain Institute, Vanderbilt University School of Medicine, Nashville, Tennessee 37232
}

The p75 neurotrophin receptor (p75NTR) plays an integral role in patterning the sympathetic nervous system during development. Initially, p75NTR is expressed at low levels as sympathetic axons project toward their targets, which enables neurotrophin-3 (NT3) to activate TrkA receptors and promote growth. Upon reaching nerve growth factor (NGF) producing tissues, p75NTR is upregulated, resulting in formation of TrkA-p75 complexes, which are high-affinity binding sites selective for NGF, thereby blunting NT3 signaling. The level of p75NTR expressed on the neuron surface is instrumental in regulating trophic factor response; however, the mechanisms by which p75NTR expression is regulated are poorly understood. Here, we demonstrate a rapid, translation independent increase in surface expression of p75NTR in response to NGF in rat sympathetic neurons. p75NTR was mobilized to the neuron surface from GGA3-postitive vesicles through activation of the GTPase Arf6, which was stimulated by NGF, but not NT3 binding to TrkA. Arf6 activation required PI3 kinase activity and was prevented by an inhibitor of the cytohesin family of Arf6 guanine nucleotide exchange factors. Overexpression of a constitutively active Arf6 mutant (Q67L) was sufficient to significantly increase surface expression of p75NTR even in the absence of NGF. Functionally, expression of active Arf6 markedly attenuated the ability of NT3 to promote neuronal survival and neurite outgrowth, whereas the NGF response was unaltered. These data suggest that NGF activation of Arf6 through TrkA is critical for the increase in p75NTR surface expression that enables the switch in neurotrophin responsiveness during development in the sympathetic nervous system.

Key words: BDNF; nerve growth factor; neurotrophin-3; p75NTR

Significance Statement

p75NTR is instrumental in the regulation of neuronal survival and apoptosis during development and is also implicated as a contributor to aberrant neurodegeneration in numerous conditions. Therefore, a better understanding of the mechanisms that mediate p75NTR surface availability may provide insight into how and why neurodegenerative processes manifest and reveal new therapeutic targets. Results from this study indicate a novel mechanism by which p75NTR can be rapidly shuttled to the cell surface from existing intracellular pools and explores a unique pathway by which NGF regulates the sympathetic innervation of target tissues, which has profound consequences for the function of these organs.

\section{Introduction}

Neurotrophin regulation of the sympathetic nervous system is intricately controlled during embryonic development to maximize

Received March 10, 2016; revised April 24, 2018; accepted May 13, 2018.

Author contributions: F.E.H. edited the paper; E.M.S. wrote the first draft of the paper. F.E.H., E.M.S., and B.D.C. designed research; F.E.H. and E.M.S. performed research; F.E.H. and E.M.S. analyzed data; F.E.H., E.M.S., and B.D.C. wrote the paper.

This work was supported by American Heart Association Grant 14POST18620038 to E.M.S. and National Institutes of Health Grants R01NS038220 and R01NS102365 to B.D.C. We thank Anders Nykjaer (Aarhus University, Aarhus, Denmark) for the gracious donation of the sortilin antibody; James Goldenring (Vanderbilt University, Nashville, TN) for the Rab11 antibody; Regeneron for the NT3 and BDNF; Cell Imaging Shared Resource Cores, Vanderbilt University for provision of, and assistance on, confocal microscopes; and members of the B.D.C. laboratory for helpful discussions.

The authors declare no competing financial interests. the limited supply of trophic support available during neuronal innervation of target tissues. These neurons depend on NGF binding to its tyrosine kinase receptor, TrkA, for their survival. However, before reaching NGF-producing targets, sympathetic axon growth is promoted by neurotrophin-3 (NT3) produced in adjacent blood vessels. Although TrkC is the preferred receptor for NT3, it is not expressed by sympathetic neurons; instead, NT3 signals through

\footnotetext{
*F.E.H. and E.M.S. contributed equally to this work.

Correspondence should be addressed to Dr. Bruce D. Carter, Department of Biochemistry and Vanderbilt Brain Institute, Vanderbilt University School of Medicine, 625 Light Hall, Nashville, TN 37232. E-mail: bruce.carter@vanderbilt.edu.

DOI:10.1523/JNEUROSCI.0788-16.2018

Copyright $\odot 2018$ the authors $\quad 0270-6474 / 18 / 385606-14 \$ 15.00 / 0$
} 
TrkA receptors, which can bind NT3 with low affinity (Birren et al., 1993; ElShamy and Ernfors, 1996; Belliveau et al., 1997; Kuruvilla et al., 2004). Once axons reach NGF-rich regions, TrkA receptors lose responsiveness to NT3 in favor of NGF to promote sympathetic neuron survival and innervation of the target (Benedetti et al., 1993; Brennan et al., 1999; Kuruvilla et al., 2004). This shift in responsiveness has been attributed to an increase in the expression of the neurotrophin receptor p75 (p75NTR), which in turn, forms a complex with TrkA. This p75NTR-TrkA complex functions as a high-affinity receptor that is very selective for NGF over NT3 (Hempstead et al., 1991). Although it is known that TrkA activation can induce p75NTR transcription, the mechanisms regulating p75NTR trafficking to the cell surface have not been investigated.

The p75NTR is a pleiotropic signaling receptor, capable of promoting survival and growth or apoptosis and degeneration, depending on the expression of its coreceptors and ligands (Kraemer et al., 2014). Whereas p75NTR-TrkA complexes elicit prosurvival and axonal growth signaling selectively in response to NGF, neurotrophin binding to p75NTR alone or binding of proneurotrophins to a complex of p75NTR and members of the Vps10p-domain family of receptors can initiate cell death and axonal degeneration (Nykjaer et al., 2004; Teng et al., 2005). Hence, precise developmental timing of p75NTR expression on the neuronal surface is critical for determining neurotrophin selectivity as well as modulating survival versus apoptotic signaling.

In considering the mechanisms by which target-derived NGF could increase p75NTR trafficking to the plasma membrane, we speculated that the GTP binding protein Arf6 may be involved. Arf6 is one of 6 related Arf GTPases (designated Arf1-6). However, unlike Arf1-5, which are primarily localized to the Golgi and endoplasmic reticulum and regulate vesicular trafficking between these two organelles (Wieland and Harter, 1999; VolpicelliDaley et al., 2005), Arf6 is localized to the plasma membrane and endosomal compartments where it plays an integral role in plasma membrane endocytosis and exocytosis, endocytic recycling, and actin cytoskeleton rearrangement (D'Souza-Schorey and Chavrier, 2006; Hongu and Kanaho, 2014). Moreover, Arf6 was recently reported to promote TrkA recycling following NGFmediated endocytosis through recruiting the adapter protein, Golgi-localized, gamma adaptin-ear-containing ADP ribosylation protein 3 (GGA3) (Li et al., 2015).

The activity of Arf proteins is regulated, in part, by guanine nucleotide exchange factors (GEFs). There are 8 GEFs that can promote Arf6 activation, including cytohesin-1, which was shown to translocate to the plasma membrane of PC12 cells in response to NGF activation of TrkA and the formation of phosphatidylinositol 3,4,5-trisphosphate (Venkateswarlu et al., 1999). Because Arf6 localizes to the plasma membrane, as well as endosomes, enrichment of cytohesin-1 at the cell surface would be predicted to locally activate Arf6, although this was not investigated. Interestingly, activation of Arf6 by another tyrosine kinase receptor, c-Met, was shown to promote recycling of the $\beta 1$-integrin receptor and increase its expression at the plasma membrane (Hongu et al., 2015). These results suggest that TrkA activation may similarly increase the expression of p75NTR on the surface of sympathetic neurons through regulation of Arf6.

In this report, we provide evidence for a rapidly occurring NGF-induced increase in p75NTR surface expression in sympathetic neurons, independent of new protein translation, caused by TrkA activation of the GTPase Arf6. Furthermore, we show that Arf6 regulation of p75NTR levels at the plasma membrane alters trophic factor responsiveness of sympathetic neurons.

\section{Materials and Methods}

Primary cell culture. All experiments conducted with tissues derived from animals were approved by the Animal Care and Use Committee at Vanderbilt University. Neurons from the superior cervical ganglia (SCG) were dissected from postnatal day 2-3 Sprague Dawley or CD1 rats (male and female; Charles River) and dissociated with $0.08 \%$ trypsin (Worthington) and $0.3 \%$ collagenase (Sigma-Aldrich). For $p 75 N T R^{-1-}$ studies, C57BL/6 mice or $p 75 \mathrm{NTR}^{-/-}$(Jackson ImmunoResearch Laboratories) SCGs were dissociated with $0.3 \%$ collagenase with $0.1 \%$ DNase for 30 $\mathrm{min}$, with $0.0 .08 \%$ trypsin added for the final $10 \mathrm{~min}$. Neurons in singlecell suspension were then plated at $\sim 5000$ neurons $/ 0.7 \mathrm{~mm}^{2}$ on 4 -well chamber slides, 8-well chamber slides (Thermo Fisher Scientific), $1 \mathrm{~mm}$ glass coverslips, or cell culture dishes coated with poly-D-lysine (overnight, MP Biomedicals) and laminin ( $\sim 2 \mathrm{~h}$, Invitrogen). Neurons were cultured in Ultraculture media (Lonza) with 3\% FBS (Denville Scientific), $2 \mathrm{~mm}$ L-glutamine (Invitrogen), $100 \mathrm{units} / \mathrm{ml}$ penicillin, and 100 $\mu \mathrm{g} / \mathrm{ml}$ streptomycin (Invitrogen) at $37^{\circ} \mathrm{C}$ in $5 \% \mathrm{CO}_{2}$. Depending on the experiment, one of the following trophic factors or supplements was added to the media to promote neuron survival: $40 \mathrm{ng} / \mathrm{ml} \mathrm{NGF} \mathrm{(Harlan}$ Laboratories), $100 \mathrm{ng} / \mathrm{ml}$ NT3 (kindly provided by Regeneron), or 12.5 $\mathrm{mm} \mathrm{KCl}$, unless otherwise specified. To prevent the proliferation of nonneuronal cells in culture, $18 \mathrm{~h}$ after initial plating cells were treated with $10 \mu \mathrm{M}$ cytosine arabinoside (Sigma-Aldrich) for 24-36 h. NGF was removed from neurons $18 \mathrm{~h}$ before GTP-activation assays by replacing NGF-containing media with media supplemented with $12.5 \mathrm{~mm} \mathrm{KCl}$ and anti-NGF antibody $(0.1 \mu \mathrm{g} / \mathrm{ml}$; Millipore Bioscience Research Reagents).

In some experiments, neurons in suspension were electroporated before plating using a rat neuron Nucleofactor kit (catalog \#VGP-1003, Amaxa Biosystems) and program G-013. Neurons were electroporated with GFP alone, or GFP and a constitutively active Arf6 (Q67L; Addgene) (Furman et al., 2002), or the Arf6 GAP ACAP1 (Addgene) (Jackson et al., 2000). Only neurons expressing GFP were used for subsequent analysis. Mouse neurons pooled from postnatal day 4-6 pups were electroporated as above and immediately divided into NGF or NT3 treatment media before plating.

Immunoprecipitation and Western blot analysis. For Arf6 assays, following NGF withdrawal, neurons were treated with NGF $(40 \mathrm{ng} / \mathrm{ml})$, NT3 (100 ng/ml), or BDNF (200 ng/ml; generously provided by Regeneron) for the indicated times, lysed, and subjected to an Arf6 activation assay (Cell Biolabs; STA-407-6) per the manufacturer's instructions. Neurons were immunoprecipitated with the provided GGA3 beads, recognizing the GTP-bound Arf6, and Arf6 was detected using a combination of monoclonal (Cell Biolabs) and polyclonal (Abcam) antibodies.

For biotinylation experiments, neurons cultured continuously in 12.5 mM KCl were treated for $2 \mathrm{~h}$ with NGF $(40 \mathrm{ng} / \mathrm{ml})$, or NGF and the Arf6 GEF inhibitor SecinH3 (50 $\mu \mathrm{M}$; Abcam) at $37^{\circ} \mathrm{C}$, followed by biotinylation of surface proteins using EZ-Link Sulfo-NHS-LC Biotin (Pierce) at $4^{\circ} \mathrm{C}$. Biotinylated proteins were immunoprecipitated with avidin agarose beads (Pierce), separated by SDS-PAGE, transferred to nitrocellulose, and p75NTR was detected with a polyclonal antibody (generated as described previously) (Kenchappa et al., 2010). The signal was visualized using anti-rabbit peroxidase-conjugated secondary antibody, enhanced chemiluminescence, and a Bio-Rad ChemiDOC MP imaging system. The band intensity was quantified using Fiji Software (Schindelin et al., 2012), normalized to total protein in the lysate fraction, and expressed as a percent control of untreated neurons.

Surface expression assays. To determine the mechanisms of NGFinduced p75NTR trafficking, neurons cultured continuously in $12.5 \mathrm{~mm}$ $\mathrm{KCl}$ were treated with $\mathrm{NGF}(40 \mathrm{ng} / \mathrm{ml})$, or NGF in combination with one of the following inhibitors: cycloheximide (CHX, $100 \mathrm{ng} / \mu \mathrm{l}$; Sigma), K252a (200 nм; Millipore), LY294002 (50 $\mu \mathrm{m}$; Sigma), or SecinH3 (50 $\mu \mathrm{M} ; \mathrm{Abcam})$ for the indicated times. At the conclusion of the time course, live, unpermeabilized cells were placed on ice and stained with an antibody for the extracellular domain of p75NTR (MC192; 1:50; Santa Cruz Biotechnology), sortilin (1:100; graciously supplied by Anders Nykjaer, Aarhus University, Aarhus, Denmark) or TrkA (sc118; 1:100; Santa Cruz Biotechnology) and cholera toxin B conjugated to Alexa-647 (CTB; 1:1000; Invitrogen) in PBS for $90 \mathrm{~min}$. Following live staining, neurons 


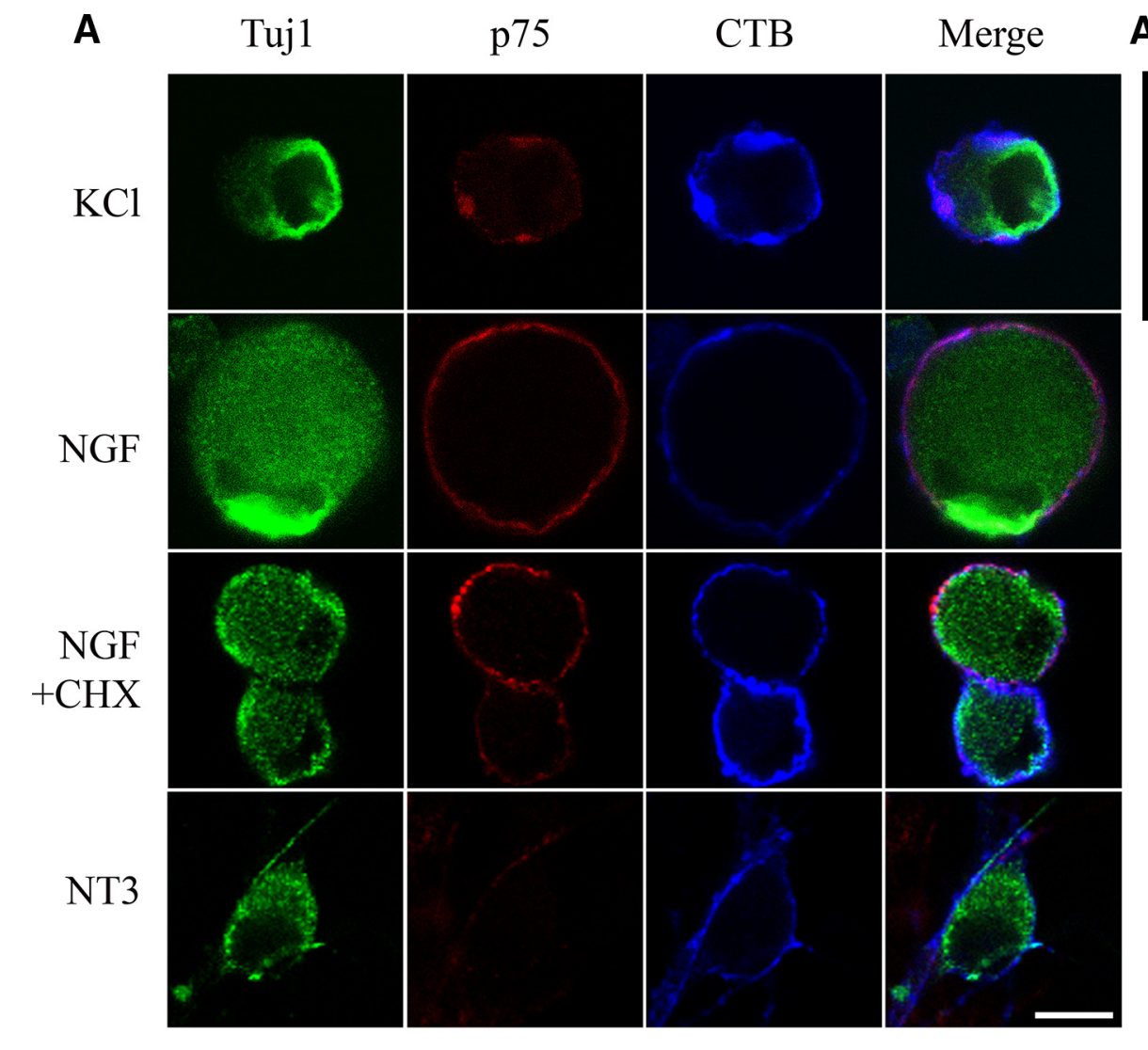

A' Intracell. p75

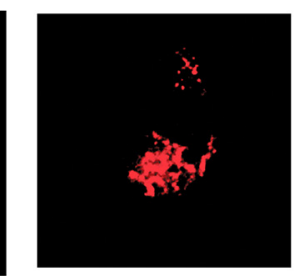

B

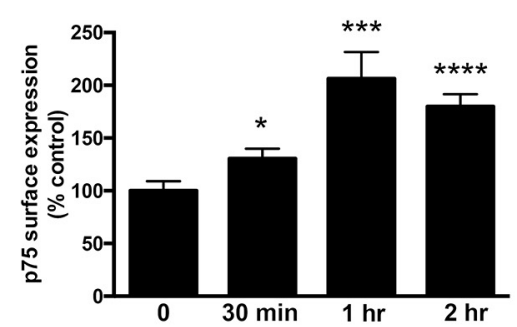

C

D
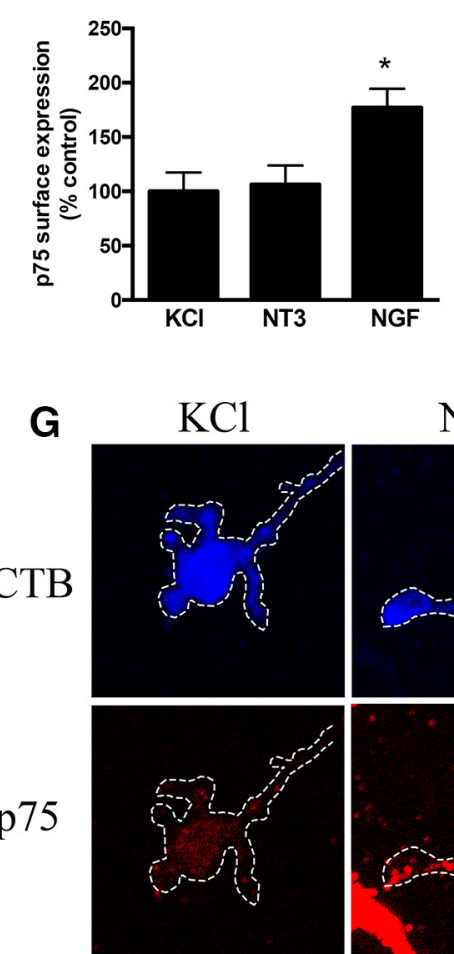

E

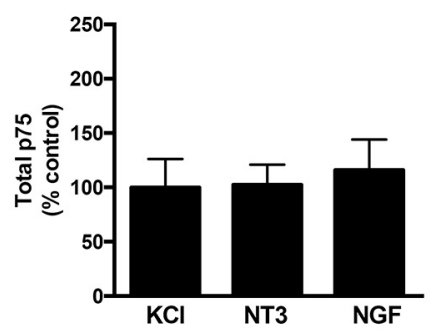

$\mathbf{F}$
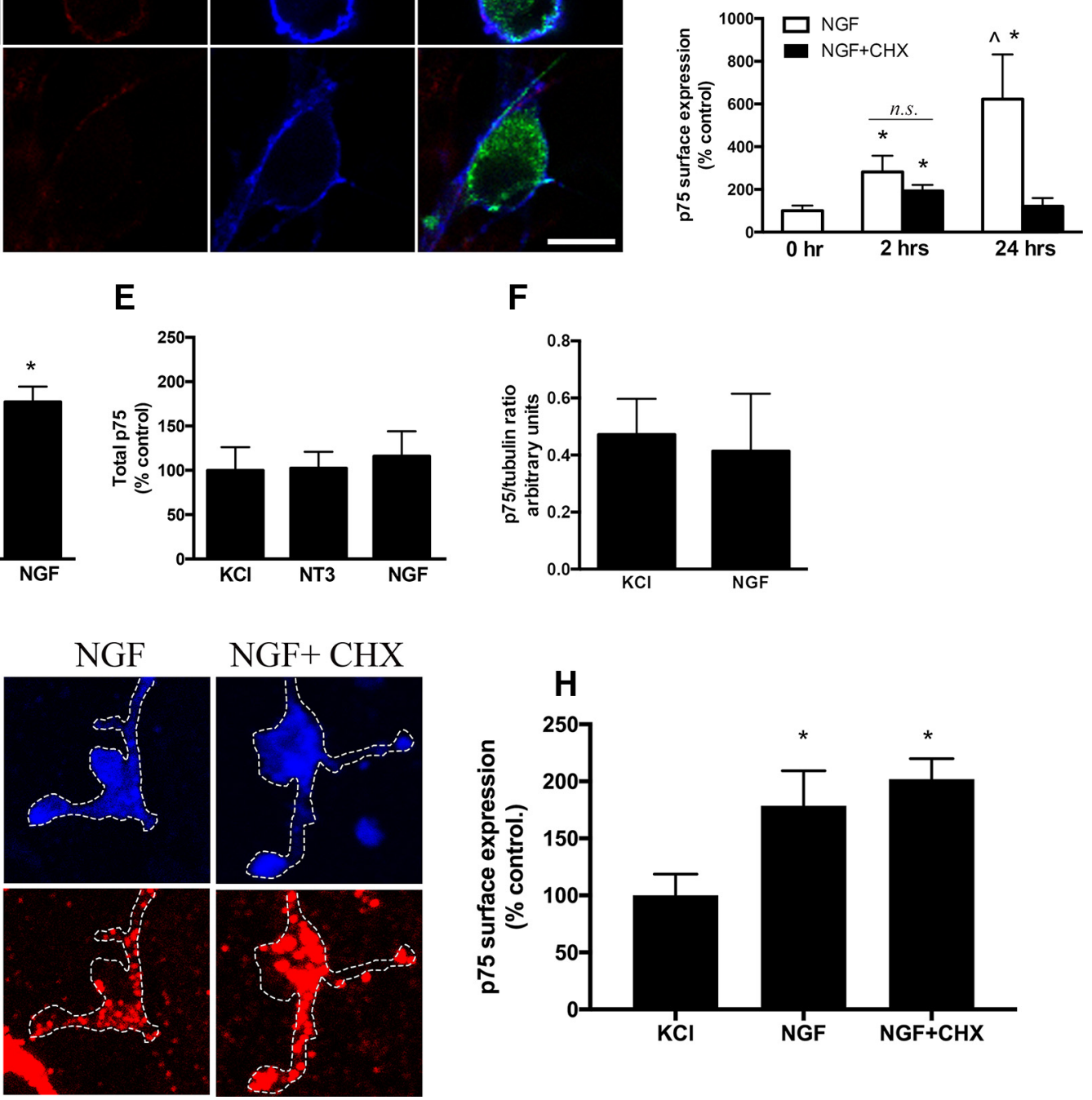

Figure 1. NGF rapidly increases p75NTR surface expression in sympathetic neurons. The surface expression of p75NTR in sympathetic neurons was quantified by immunolabeling live neurons with an antibody to the extracellular domain of the receptor and fluorescently conjugated cholera toxin B to define the cell surface, followed by fixation and immunostaining for the neuron-specific marker TuJ1 or neurofilament. $A$, Representative images of p75NTR expression in neurons cultured in KCl (12.5 mM) (white circled neuron, top row), treated for $2 \mathrm{~h}$ with NGF (40 ng/ml) alone or together with cycloheximide $(100 \mathrm{ng} / \mathrm{ml})$ or treated with NT-3 $(100 \mathrm{ng} / \mathrm{ml}) . A^{\prime}$, Immunostaining for p75NTR in permeabilized neurons cultured in KCl, revealing the presence of intracellular p75NTR. $B, C$, The level of p75NTR fluorescence intensity following treatment with NGF for the indicated time was determined by confocal imaging and quantified using Fiji software. $\boldsymbol{D}$, The expression of p75NTR at the cell surface in response to $2 \mathrm{~h}$ exposure to NGF was compared with treatment with NT3 $(100 \mathrm{ng} / \mathrm{ml})$ by quantification of fluorescence intensity. $E$, The total level of p75NTR expression was not altered after $2 \mathrm{~h}$ treatment with NGF or NT3, as quantified after permeabilizing the neurons and immunolabeling the receptor. $\boldsymbol{F}$, Western blot analysis of (Figure legend continues.) 
were fixed with $4 \%$ PFA ( $25 \mathrm{~min}$ at room temperature). Some neurons were stained with anti-Tuj1 (1:1000; Covance) or anti-neurofilament (1:1000; Millipore), and primary antibodies were visualized with appropriate AlexaFluor-conjugated secondary antibodies (1:1000; Invitrogen). Tuj1 or neurofilament-positive cells and GFP electroporated neurons were imaged in a single optical slice using a $63 \times$ oil-immersion objective on a TCS SP5 confocal microscope equipped with LAS AF software (Leica Microsystems), and surface intensity of individual neurons was determined using Fiji Software, where a standard threshold was applied to each image before intensity assessment. The images were analyzed in a blinded manner. Approximately 25-30 neurons per condition were sampled for each experiment. Average surface intensity per condition was normalized and expressed as percent control.

Immunocolocalization analysis. For p75NTR-GGA3 colocalization analysis, rat SCG primary neurons were electroporated with a pEGFP-N1 construct containing GGA3 fused to EGFP ( $5 \mu \mathrm{g}$, generously provided by Dr. Guangyu $\mathrm{Wu}$ ) and initially cultured for $18 \mathrm{~h}$ in $12.5 \mathrm{~mm} \mathrm{KCl}$ before the addition of NGF for $2 \mathrm{~h}$. Fixed, permeabilized neurons were stained for p75NTR (1:50, MC192) and anti-GFP (1:1000, Abcam) and counterstained with neurofilament (NF, 1:1000, Millipore) to mark neurons. Approximately $1 \mu \mathrm{m}$ sections of $\mathrm{GFP}^{+}, \mathrm{NF}^{+}$neurons were imaged in $0.16 \mu \mathrm{m}$ slices on a Zeiss LSM 880 confocal with Airyscan. Postprocessed images were analyzed using the Coloc2 plugin in Fiji, and Pearson's $R$ coefficients were computed between GGA3 and p75NTR channels. For further intracellular compartment colocalization analysis, unelectroporated rat SCG neurons were initially cultured in $12.5 \mathrm{~mm} \mathrm{KCl}$ before the addition of NGF for $2 \mathrm{~h}$. Fixed, permeabilized neurons were stained for p75NTR (1:50, MC192) and Rab11 (1:250, VU57 antibody generously provided by Dr. Jim Goldenring). Colocalization analysis was completed as described above.

Survival assays. Neurons were initially cultured for $2 \mathrm{~d}$ in $12.5 \mathrm{~mm} \mathrm{KCl}$ before addition of increasing concentrations of NT3 $(2.5-100 \mathrm{ng} / \mathrm{ml})$ or NGF $(0.2-40 \mathrm{ng} / \mathrm{ml})$, or removal of $\mathrm{KCl}$ entirely (starved condition) for 48 h. Fixed, permeabilized neurons were stained with anti-Tuj1 and visualized with appropriate AlexaFluor-conjugated secondary antibodies. Slides were imaged using a Zeiss Axioskope 2 fluorescent microscope equipped with an AxioCam MRc5 camera and AxioVision software (Carl Zeiss), and 10 randomized fields were captured per condition per experiment. Neurons were classified as nonapoptotic or apoptotic by blinded assessment of DAPI nuclear staining, as previously described (Kenchappa et al., 2010).

Neurite outgrowth analysis. Rat sympathetic neurons were electroporated with GFP $(1 \mu \mathrm{g})$ alone, or GFP and a constitutively active Arf6 (Q67L) $(5 \mu \mathrm{g})$, and immediately plated into media containing either 40 $\mathrm{ng} / \mathrm{ml} \mathrm{NGF}$ or $100 \mathrm{ng} / \mathrm{ml} \mathrm{NT3}$. Neurons were fixed after $16 \mathrm{~h}$ and counterstained for with anti-GFP (1:1000, Abcam) and neurofilament (1:1000, Millipore) to visualize electroporated cells and neurites, respectively. Electroporated neurons were imaged using Nikon Eclipse Ti inverted fluorescent microscope. The longest neurite for each $\mathrm{GFP}^{+}$neuron was measured in a blinded manner using Fiji software. Mouse wild-type or p75NTR ${ }^{-1-}$ neurons were electroporated with GFP and Arf (Q67L) and immediately plated into media containing either $40 \mathrm{ng} / \mathrm{ml}$ NGF or 100 $\mathrm{ng} / \mathrm{ml}$ NT3. Neurons were fixed after $48 \mathrm{~h}$ and counterstained for with anti-GFP (1:1000, Abcam) and neurofilament (1:1000, Millipore) and analyzed as above.

Statistical analysis. Data are presented as mean \pm SEM and expressed as a percentage of the control mean for each experiment. Means were compiled for each condition, and outliers detected using a Grubbs' test were replaced with the average of the means. These data were analyzed

\section{$\leftarrow$}

(Figure legend continued.) total neuronal p75NTR expression with or without $2 \mathrm{~h}$ NGF treatment. The signal was quantified and normalized to tubulin $(n=3) .{ }^{*} p \leq 0.05$, compared with 0 NGF. ${ }^{* * *} p \leq 0.001$, compared with 0 NGF. $\wedge p \leq 0.05$ compared with $24 \mathrm{~h}$ NGF. Scale bar, $10 \mu \mathrm{m}$. $G$, Representative images of sympathetic neuron growth cones pretreated for $1 \mathrm{~h}$ with $10 \mu \mathrm{M}$ CHX followed by KCl, NGF, or NGF + CHX for $2 \mathrm{~h}$ before staining for p75NTR in unpermeabilized conditions. CTB was used to show the growth cone membrane. $\boldsymbol{H}$, Quantification of p75NTR surface intensity in pixels per area of growth cone $(n=3) .{ }^{*} p<0.05$. using a one-way ANOVA with a planned independent-samples $t$ test post hoc on the means contributing to the significance of the variance. For experiments with only 2 datasets, the results were analyzed by an unpaired Student's $t$ test. Two sample sets were considered significantly different when $p<0.05$. All statistical analysis was performed and graphed in GraphPad Prism, version 6.0 (GraphPad Software).

\section{Results}

\section{p75NTR surface expression is rapidly upregulated by NGF}

Previous studies have shown that sympathetic neurons and neuroblasts treated with NGF increase transcription of p75NTR (Miller et al., 1994; Verdi and Anderson, 1994; Wyatt and Davies, 1995). However, given the time required for transcription, translation, and trafficking of p75NTR to the distal axon, and the very rapid pace of early mammalian development, we considered the possibility that NGF could more acutely induce surface p75NTR expression. Here, we introduce a novel, rapid upregulation of surface-expressed p75NTR induced by NGF starting as early as $30 \mathrm{~min}$ and persisting for up to $2 \mathrm{~h}$, resulting in nearly a twofold increase over baseline expression (Fig. $1 A, B ; F_{(3,94)}=10.17, p<0.0001$ ). Because sympathetic neurons are dependent on NGF for survival, we initially cultured the neurons in $\mathrm{KCl}(12.5 \mathrm{~mm})$ to promote neuronal survival in the absence of trophic factor support. Surface expression of p75NTR was imaged in live neurons using an antibody directed to the extracellular domain of p75NTR (red), and Alexa-647 conjugated to CTB (blue) to define the cell membrane. Importantly, the NGF-induced increase in surface p75NTR was not blocked by coadministration of the translational inhibitor CHX, whereas long-term application (24 h) of NGF and CHX prevented the upregulation of p75NTR at the plasma membrane (Fig. $1 A, C ; F_{(4,25)}=4.338, p=0.0084$ ). These results suggest that the rapid increase in surface-expressed p75NTR is sourced from existing intracellular p75NTR, evident in permeabilized neurons immunolabeled with p75NTR (Fig. $1 A^{\prime}$ ). Translocation of p75NTR from intracellular storage pools to the cell surface was specific for NGF, as NT3 elicited no change in p75NTR surface expression (Fig. $1 D ; F_{(2,9)}=4.79, p=0.038$ ). Assessment of total p75NTR in permeabilized neurons and sympathetic neuron lysates indicated that neither neurotrophin altered total p75NTR expression following an acute, $2 \mathrm{~h}$ treatment (Fig. $1 E, F$ ).

We also investigated the effects of BDNF, which only binds to p75NTR in sympathetic neurons, to determine whether p75NTR upregulation could be a positive feedback system from this receptor. However, acute administration of BDNF did not significantly alter the surface expression of p75NTR within $2 \mathrm{~h}$ of treatment $(\mathrm{KCl}=100 \pm 12.5 \mathrm{vs} \mathrm{BDNF}=110 \pm 20.5, p=0.96)$.

Because the rapid recruitment of p75NTR to the cell surface would be expected to occur first at the nerve terminals, as the sympathetic axons reach NGF-producing target tissues, we tested whether the p75NTR upregulation could also be detected in growth cones. After $2 \mathrm{~h}$ of NGF treatment, there was an approximately twofold increase in surface expression of p75NTR, specifically on growth cones; this was unaffected by coadministration of CHX with NGF (Fig. $1 G, H ; F_{(2,150)}=1.47, p=0.03$ ) and in agreement to what we detected in the neuron cell bodies.

Interestingly, the induction of p75NTR surface expression by NGF appeared specific for neurons, as satellite glial cells (which do not express TrkA receptors) maintained high levels of surface p75NTR, even in the absence of neurotrophic support (Fig. 2A). To determine whether the effects of NGF on receptor trafficking were specific to p75NTR, we assessed TrkA (Fig. 2B) and sortilin (Fig. 2C) surface expression within the first $2 \mathrm{~h}$ of treatment but observed no significant alterations. Cycloheximide 


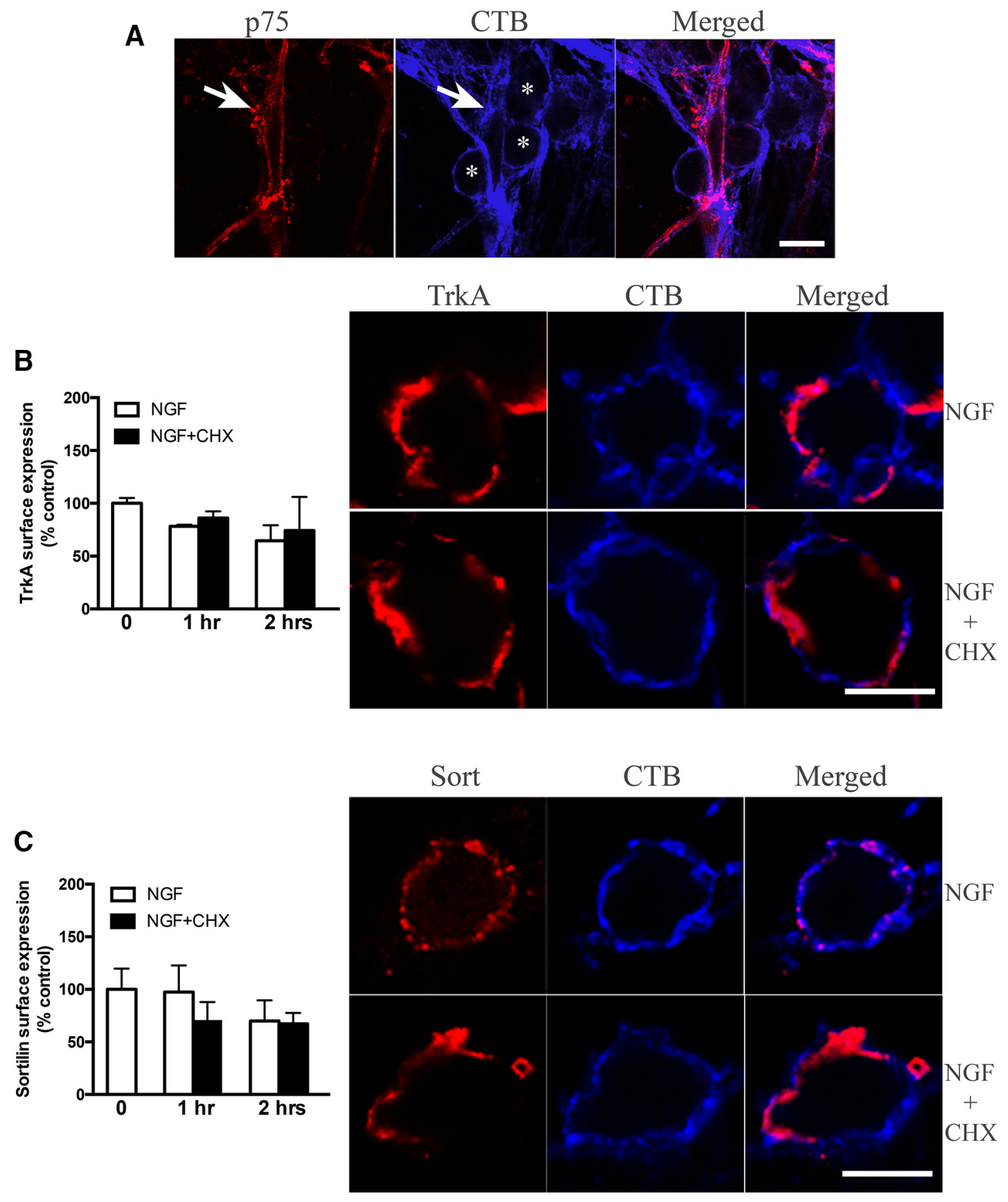

Figure 2. Rapid regulation of neurotrophin receptor expression by NGF is specific for neuronal p75NTR. $A$, Expression of p75NTR on the surface of satellite glial cells present in cultures of sympathetic neurons grown in $\mathrm{KCl}(12.5 \mathrm{~mm})$ was detected by immunolabeling p75NTR in live cells with an antibody to the extracellular domain of the receptor. The cell surface was defined using fluorescently labeled (TB. The glial cells maintain robust p75NTR surface expression (white arrow), whereas sympathetic neurons in the same culture exhibit very low expression of p75NTR on the cell surface (white asterisks). The surface level of TrkA (B) or sortilin (C) following treatment with NGF ( $40 \mathrm{ng} / \mathrm{ml}$ ) with or without CHX ( $100 \mathrm{ng} / \mathrm{ml})$ for 0,1 , or $2 \mathrm{~h}$ was determined by immunostaining live neurons with an antibody to the extracellular domain of each receptor. The level of receptor at the cell surface was determined by confocal imaging and fluorescence intensity quantified using Fiji software (representative images are shown on the right). There was no significant change in the surface expression of TrkA or sortilin following NGF treatment, with or without CHX ( $n=2$ or 3 ). Scale bars, $10 \mu \mathrm{m}$.

also did not have a significant effect on the expression of these receptors within this time frame. These data indicate that NGF induces a rapid, translation-independent increase in surface expression specifically of the p75NTR in sympathetic neurons.

\section{NGF increases p75NTR surface expression by activation of Arf6}

A growing body of literature has pointed to the GTPase Arf6 as a pivotal regulator of vesicular trafficking and receptor recycling
(D'Souza-Schorey and Chavrier, 2006), including the neurotrophin receptor TrkA (Li et al., 2015); therefore, we considered the possibility that NGF may induce p75NTR shuttling to the plasma membrane through activation of Arf6. To determine whether NGF stimulates Arf6 in sympathetic neurons, we applied NGF acutely ( $0-30 \mathrm{~min})$ and assessed activation by pull-down of the GTP-bound form of Arf6 using GGA3-coupled beads (Fig. 3A). Peak activation of the GTPase occurred after 15 min of NGF treatment and began to abate after $30 \min \left(F_{(3,14)}=5.272, p=\right.$ 

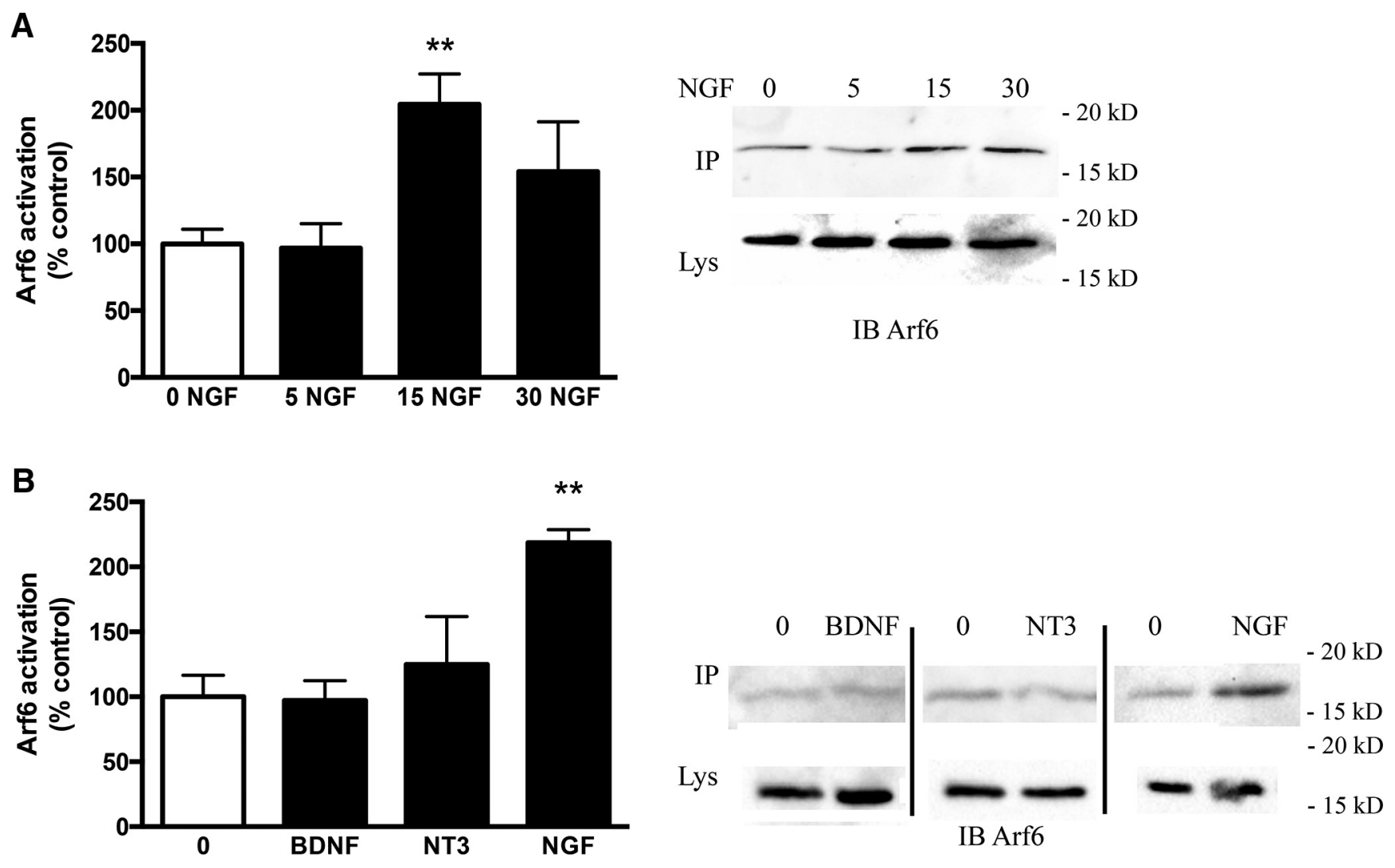

Figure 3. NGF induces activation of Arf6. A, NGF was withdrawn from sympathetic neurons and replaced with KCl for $\sim 18 \mathrm{~h}$; then neurons were exposed to NGF ( $40 \mathrm{ng} / \mathrm{ml}$ ) for the indicated time, lysed, and the activated Arf6 determined by pulldown of the GTP bound form with GGA3-coupled beads and Western blot for Arf6 (IP). The lysates were also blotted for total Arf6 (Lys) and the ratio of the active to total used to quantify the fraction of active Arf6, which was expressed as a percentage of neurotrophin naive control. NGF induced a significant increase in GTP-bound Arf6 after 15 min that began to abate after $30 \mathrm{~min}$. $\boldsymbol{B}$, The activation of Arf6 in the neurons was specific for NGF, as $15 \mathrm{~min}$ treatment with BDNF ( $100 \mathrm{ng} / \mathrm{ml})$ or NT3 (100 ng/ml) did not alter the activity of Arf6 $(n=3-5)$. ${ }^{* *} p \leq 0.01$, compared with 0 .

0.012). Similar kinetics of Arf6 activation were recently reported for NGF in PC12 cells (Li et al., 2015). Importantly, the activation detected in the sympathetic neurons was selective for NGF, as 100 $\mathrm{ng} / \mathrm{ml} \mathrm{NT3}$ or BDNF was insufficient to elicit GTP-binding of Arf6 (Fig. $3 B ; F_{(3,10)}=4.684, p=0.027$ ). Because BDNF only binds to p75NTR, and not p75NTR in complex with TrkA, in sympathetic neurons, this result indicates that the receptor does not activate Arf6 to regulate its own expression. NT3 is able to bind TrkA and can promote survival of the neurons at this concentration (Belliveau et al., 1997) (see Fig. 6); however, it was unable to activate Arf6, which correlates with its inability to increase p75NTR at the cell surface (Fig. 1D).

To directly evaluate the ability of Arf6 to regulate p75NTR surface expression, sympathetic neurons were electroporated with the constitutively active (CA) Arf6 mutant, Q67L and p75NTR surface expression was assessed using confocal microscopy (Fig. 4). Neurons electroporated with CA Arf6 displayed a significant increase in p75NTR surface expression in the absence of NGF $(100 \pm 18$ vs $234 \pm 45, p=0.026)$. Even when the neurons were continuously exposed to NGF, CA Arf6 was able to further upregulate $\mathrm{p} 75 \mathrm{NTR}(100 \pm 13$ vs $176 \pm 30, p=0.032)$. Conversely, when we electroporated neurons with the Arf6 GAP, ACAP1, which effectively inhibits Arf6 by inducing conversion to the GDP-bound state, there was a significant reduction in surfaceexpressed p75NTR, even when cultured in NGF-containing media $(100 \pm 9$ vs $70 \pm 10, p=0.048)$. These data demonstrate that sustained activation or inactivation of Arf6 is sufficient to regulate the level of accessible p75NTR at the neuronal surface.
NGF increases surface p75NTR through a TrkA-PI3 kinase-Arf6 pathway

In sympathetic neurons, NGF binds to TrkA receptors to elicit prosurvival signaling through well-characterized signaling cascades, including activation of phosphoinositide 3-kinase (PI3K) (Deinhardt and Chao, 2014). Interestingly, it was previously reported that NGF stimulated recruitment of the Arf6 GEF cytohesin- 1 to the plasma membrane through activation of PI3K in PC12 cells (Venkateswarlu et al., 1999). Therefore, we hypothesized that NGF-induced p75NTR surface expression requires TrkAmediated activation of PI3K, leading to stimulation of Arf6. To test our hypothesis, we first acutely treated sympathetic neurons with NGF, or NGF combined with the Trk inhibitor K252a, and measured the level of p75NTR at the plasma membrane. As predicted, inhibition of TrkA prevented the NGF-induced increase in surface p75NTR (Fig. $5 A ; F_{(6,49)}=2.468, p=0.035$ ). To determine whether PI3K was required for the effects of NGF, we used the selective PI3K inhibitor LY294002. Neurons treated with NGF in the presence of LY294002 failed to upregulate p75NTR (Fig. $\left.5 B ; F_{(6,28)}=4.66, p=0.0021\right)$. In contrast, an inhibitor of the ERK pathway (U0126, $10 \mu \mathrm{M}$ ) had no effect on p75NTR trafficking (NGF alone increased p75NTR surface expression $71.01 \pm 2.47 \%$, and NGF+U0126 increased it $66.32 \pm 29.78 \%$, $p=0.90)$. Finally, to further establish a role for Arf6 in the effects of NGF on p75NTR expression, we tested SecinH3, which inhibits the cytohesin family of Arf6 GEFs. When SecinH3 was added together with NGF, there was no increase in the levels of surface p75NTR (Fig. $5 C ; F_{(6,28)}=5.343, p=0.0009$ ). 


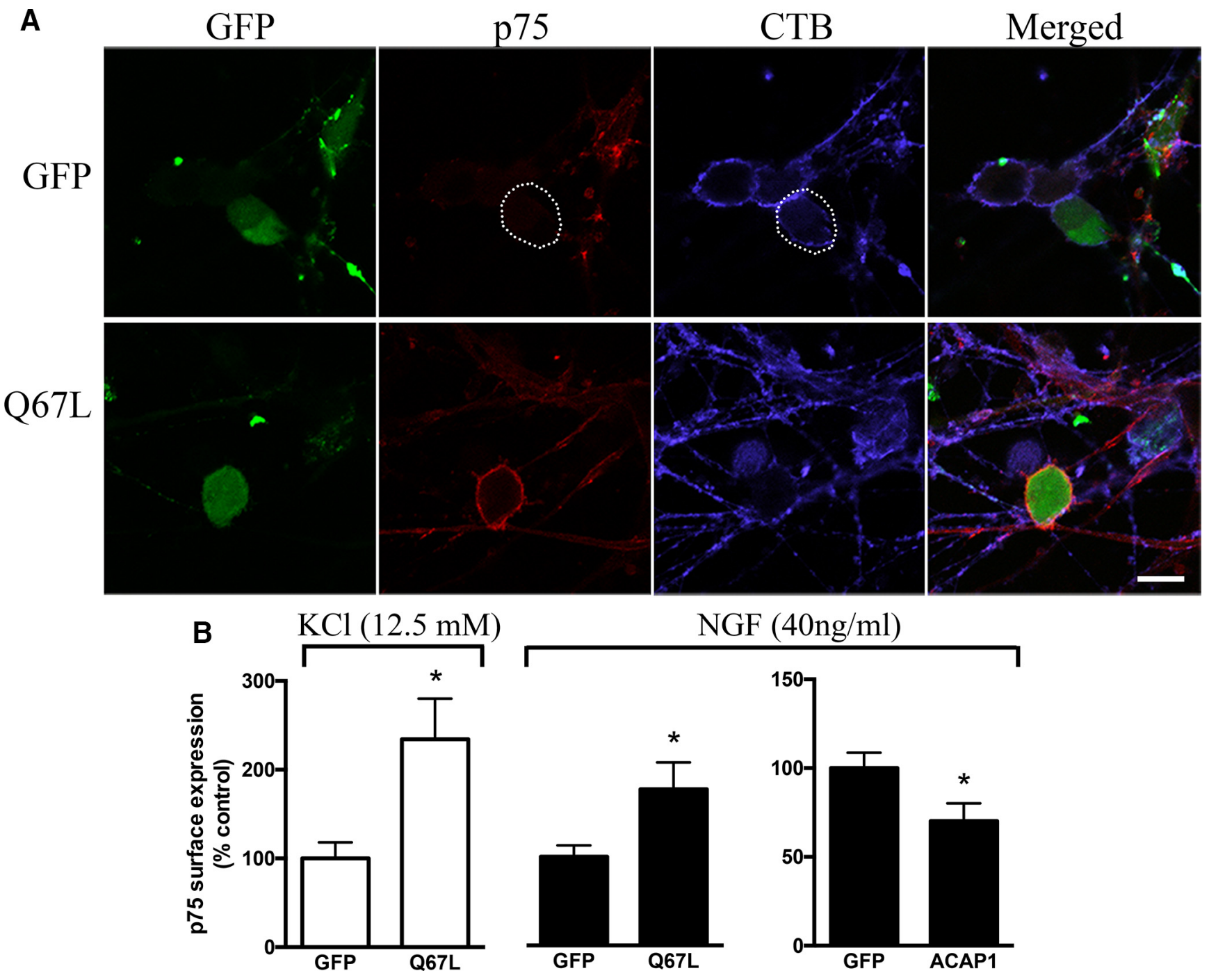

Figure 4. Arf6 regulates p75NTR surface expression. Sympathetic neurons were electroporated with a plasmid expressing GFP (top) or GFP and Q67L Arf6 (bottom) or the Arf6 GAP, ACAP1, then cultured with KCl or NGF. After $3 \mathrm{~d}$, the surface expression of p75NTR in sympathetic neurons was quantified by immunolabeling live neurons with an antibody to the extracellular domain of the receptor, followed by fixation, confocal imaging, and measurement of fluorescence intensity using Fiji software. To define the surface of the cells, fluorescently labeled CTB was added to live neurons during immunostaining. $A$, Representative images of p75NTR expression on the cell surface in neurons cultured in KCl after electroporation with a vector expressing GFP or GFP and Q67L Arf6. Note the absence of p75NTR in GFP controls (white circle) but increased surface expression in the presence of Q67L Arf6. B, Quantification of p75NTR surface expression in neurons cultured with KCI (white bars) or $40 \mathrm{ng} / \mathrm{ml} \mathrm{NGF} \mathrm{(black} \mathrm{bars).} \mathrm{The} \mathrm{signal} \mathrm{is} \mathrm{expressed} \mathrm{as} \mathrm{a} \mathrm{percentage} \mathrm{relative} \mathrm{to} \mathrm{neurons} \mathrm{expressing} \mathrm{GFP} \mathrm{alone}(n=5-7) .{ }^{*} p \leq 0.05$, compared with GFP electroporated controls. Scale bar, $10 \mu \mathrm{m}$.

To provide a complimentary biochemical assessment to the upregulation of p75NTR by NGF, we used surface biotinylation assays. Sympathetic neurons were cultured in $\mathrm{KCl}$ and then treated for $2 \mathrm{~h}$ with NGF in the presence or absence of SecinH3. The neurons were then placed on ice and surface proteins biotinylated. The biotinylated proteins were pulled down from neuronal lysates with streptavidin beads and blotted for p75NTR. It is likely that the basal level of surface p75NTR, in the absence of $\mathrm{NGF}$, is overestimated in this assay because there are some glial cells present in the cultures (despite treatment with cytosine arabinoside), which constitutively express p75NTR at the cell surface (Fig. 2A). Nevertheless, corroborating our imaging results, NGF induced a significant increase in the level of p75NTR at the cell surface, which was inhibited by SecinH3 (Fig. $5 D ; F_{(2,6)}=6.574$, $p=0.038$ ). Collectively, these data support a TrkA-mediated, PI3Kdependent rapid regulation of p75NTR trafficking by the GTPase Arf6.

\section{NGF mobilizes a pool of p75NTR in GGA3 vesicles}

NGF was recently shown to activate Arf6 in PC12 cells, which promoted TrkA recycling through association with GGA3 (Li et al., 2015). Therefore, we considered the possibility that p75NTR could also be recruited to GGA3-containing vesicles and shuttled to the plasma membrane with TrkA. Surprisingly, however, a substantial pool of the p75NTR was found to preexist in GGA3 ${ }^{+}$ vesicles, before any NGF treatment. In contrast to TrkA, NGF induced a significant reduction in the colocalization of p75NTR and GGA3 (Fig. 6A-C; Pearson's coefficient for $\mathrm{KCl}$ alone: $0.47 \pm$ 0.03 vs $0.28 \pm 0.05$ for $2 \mathrm{~h}$ NGF treatment, $p=0.028$ ). These results suggest that the neurons store rapidly accessible p75NTR in $\mathrm{GGA}^{+}$vesicles before reaching their targets and that, upon exposure to NGF, TrkA activates Arf6 to recruit GGA3 from these vesicles and enable p75NTR to traffic to the cell surface.

In addition to the p75NTR localized to $\mathrm{GGA} 3^{+}$vesicles, there was an additional pool of intracellular receptor that was not 

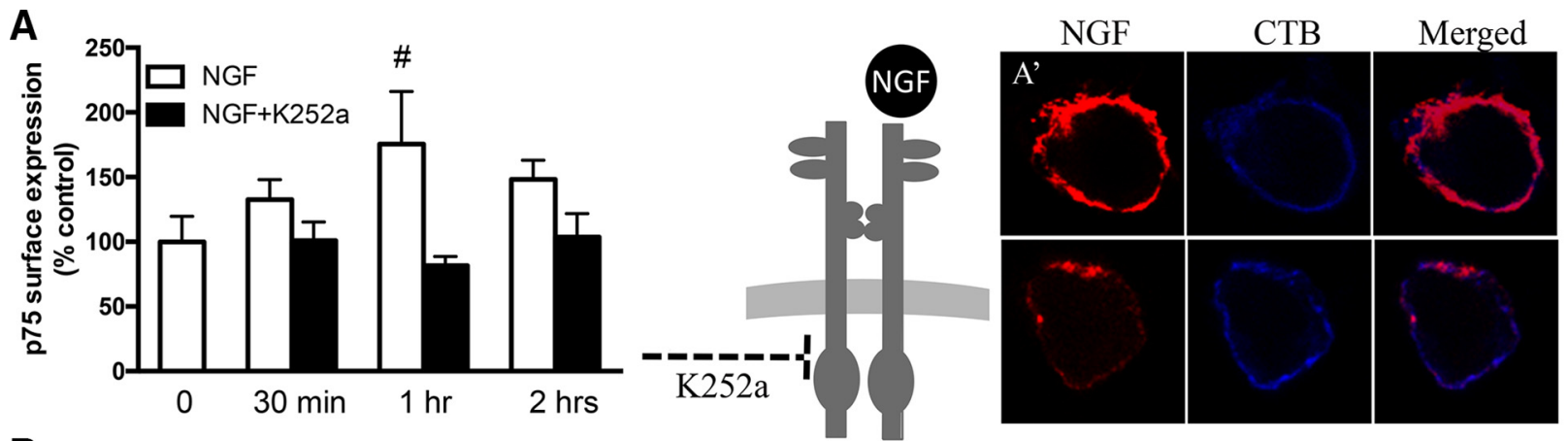

NGF
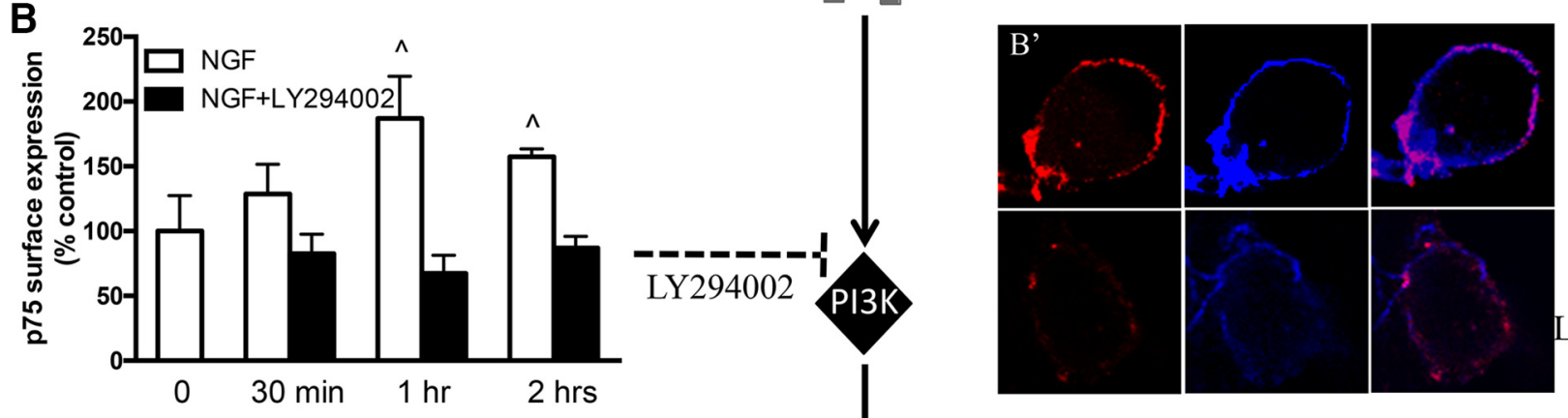

NGF

NGF

K252a
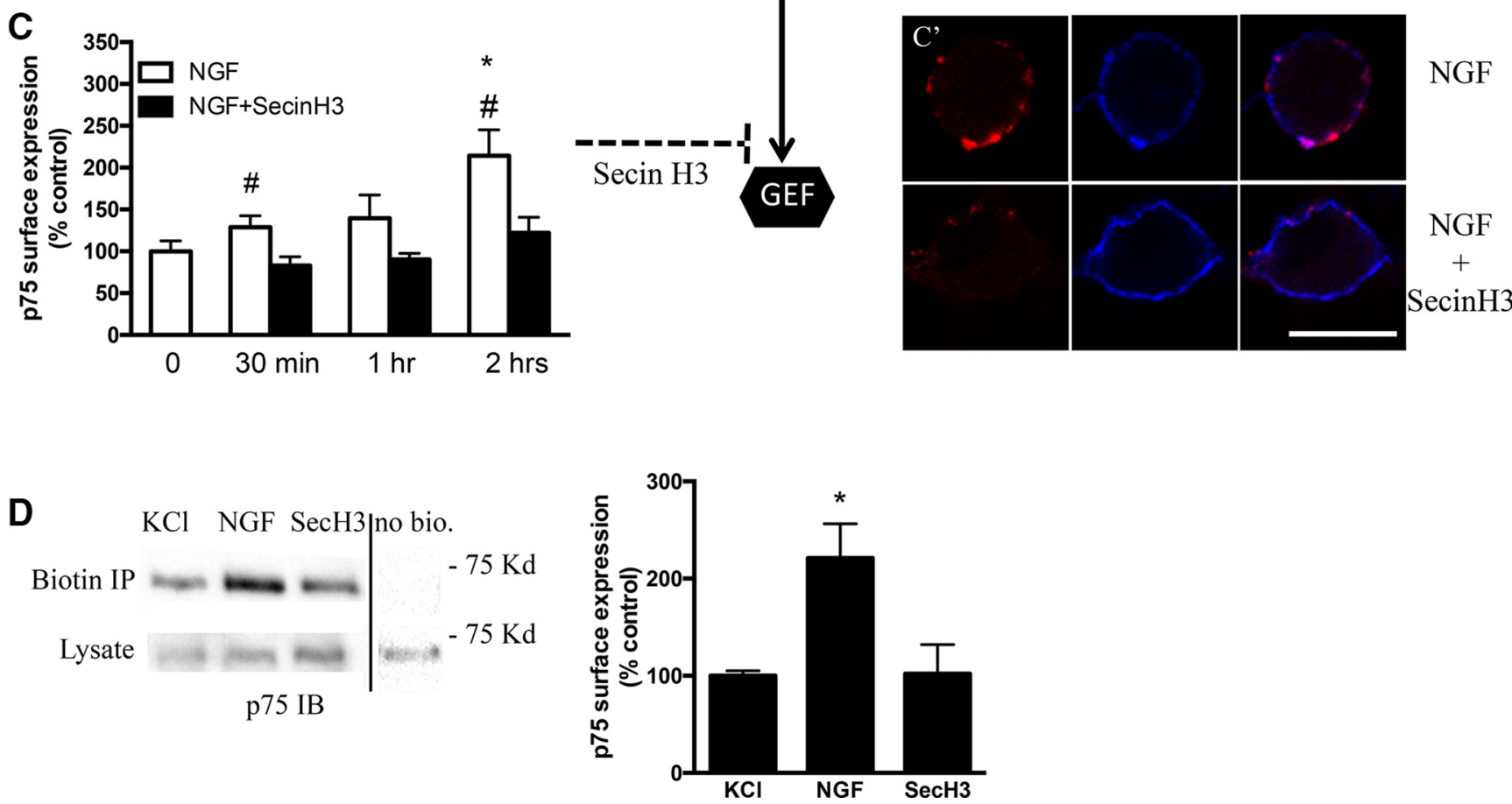

Figure 5. NGF upregulates p75NTR surface expression through a TrkA-PI3 kinase-Arf6 pathway. Sympathetic neurons were treated with $40 \mathrm{ng} / \mathrm{ml}$ NGF for the indicated time in the absence or presence of $(\boldsymbol{A})$ the Trk inhibitor K252a $(200 \mathrm{~nm}),(\boldsymbol{B})$ the PI3 kinase inhibitor LY294002 $(50 \mu \mathrm{M})$, or ( $\boldsymbol{C}$ the Arf6 GEF inhibitor SecinH3 (50 $\mu \mathrm{m})$. The level of p75NTR surface expression was evaluated by immunostaining in unpermeabilized cells; and after fixation, the fluorescence intensity was visualized by confocal imaging and quantified using Fiji software and expressed as a percentage relative to neurons cultured in $\mathrm{KCl}$ in the absence of NGF. To define the surface of the cells, fluorescently labeled CTB was added to live neurons during immunostaining (representative images are shown on the right). D. Cell surface p75NTR was also quantified by biotinylation assay. Neurons were cultured in KCl, then treated with NGF with or without SecinH3 (SecH3, $50 \mu \mathrm{m}$ ) for $2 \mathrm{~h}$, then placed at $4^{\circ} \mathrm{C}$, and the surface proteins biotinylated. The neurons were then lysed and biotinylated proteins precipitated with streptavidin beads and immunoblotted for p75NTR. To control for nonspecific pulldown of p75NTR, the biotinylation reagent was omitted in one sample (no bio). The band intensity was quantified and normalized to the level of p75NTR in the lysate and expressed as a percentage of $\mathrm{KCl}$ control $(n=3-8) .{ }^{*} p \leq 0.05$, compared with control. ${ }^{*} p \leq 0.05$, compared with time-paired inhibitors. $\wedge p \leq 0.001$, compared with time-paired inhibitors.

associated with GGA3. Although some of this was likely newly translated p75NTR, we also considered the possibility that there could be a readily accessible pool of p75NTR localized to recycling vesicles. Bronfman and colleagues recently demonstrated that p75NTR traffics to Rab $11^{+}$recycling endosomes following NGF-induced internalization in PC12 cells (Escudero et al.,
2014). Because of the role of Rab11 in membrane recycling and the known association of Rabs with Arf6 (Zerial and McBride, 2001; Hutagalung and Novick, 2011; Hongu and Kanaho, 2014), we hypothesized that Rab $11^{+}$vesicles could be additional storage vesicles for intracellular p75NTR. However, upon assessing the internal distribution of p75NTR and Rab11, we found only a 
small fraction of p75NTR coexpressed with Rab $11^{+}$endosomes, but that did not significantly change upon NGF treatment (Fig. 6D). These data indicate that there is a specific pool of p75NTR in GGA3 ${ }^{+}$vesicles that can be rapidly recruited to the plasma membrane upon NGF activation of TrkA.

NT3-mediated neuronal survival and neurite outgrowth is inhibited by activated Arf6

Previous studies have indicated that p75NTR expression modulates the responsiveness of TrkA to NT3; for example, NT3 is more potent in activating TrkA and promoting neurite growth and survival in neurons from $p 75 \mathrm{NTR}^{-/-}$mice (Lee et al., 1994; Kuruvilla et al., 2004). Furthermore, p75NTR expression is markedly increased as sympathetic neurons innervate their NGF-producing target fields, which has been suggested to shift the responsiveness of the neurons from NT3 to NGF (Kuruvilla et al., 2004). Therefore, we hypothesized that the upregulation of p75NTR surface expression induced by activation of Arf6 would attenuate the ability of the neurons to respond to NT3. To test this hypothesis, we electroporated sympathetic neurons with GFP, or the CA mutant of Arf6 and performed neurotrophin survival assays. Neurotrophin naive neurons were treated with increasing concentrations of NGF or NT3 for $48 \mathrm{~h}$ and neuron survival was determined by evaluation of DAPI-stained nuclei. While electroporated neurons exhibited no alterations in NGF-mediated survival compared with unelectroporated controls (Fig. 7A), neurons expressing the Q67L CA Arf6 construct showed no trophic response to NT3 compared with both unelectroporated controls and GFP-expressing neurons (Fig. 7B; $\left.F_{(10,36)}=4.255, p=0.006\right)$.

Because NT3 is best characterized as promoting neurite outgrowth during development of the sympathetic nervous system (Kuruvilla et al., 2004), we also investigated the effects of NT3 in neurons expressing CA Arf6. Sympathetic neurons electroporated with GFP only or GFP and CA Arf6 were treated with NGF or NT3 for $18 \mathrm{~h}$, then the longest neurite from each $\mathrm{GFP}^{+}$cell was measured. The outgrowth from neurons expressing GFP only was not different in those treated with

NGF compared with NT3. However, in neurons expressing the CA Arf6 construct, NT3-induced neurite outgrowth was significantly less than NGF-induced outgrowth. Similarly, NT3 promoted longer neurites in neurons expressing GFP only, as control, relative to those expressing CA Arf6 (Fig. $7 C, D ; F_{(3,12)}=$ $1.4, p=0.011)$. To confirm that this change in neurotrophin re-
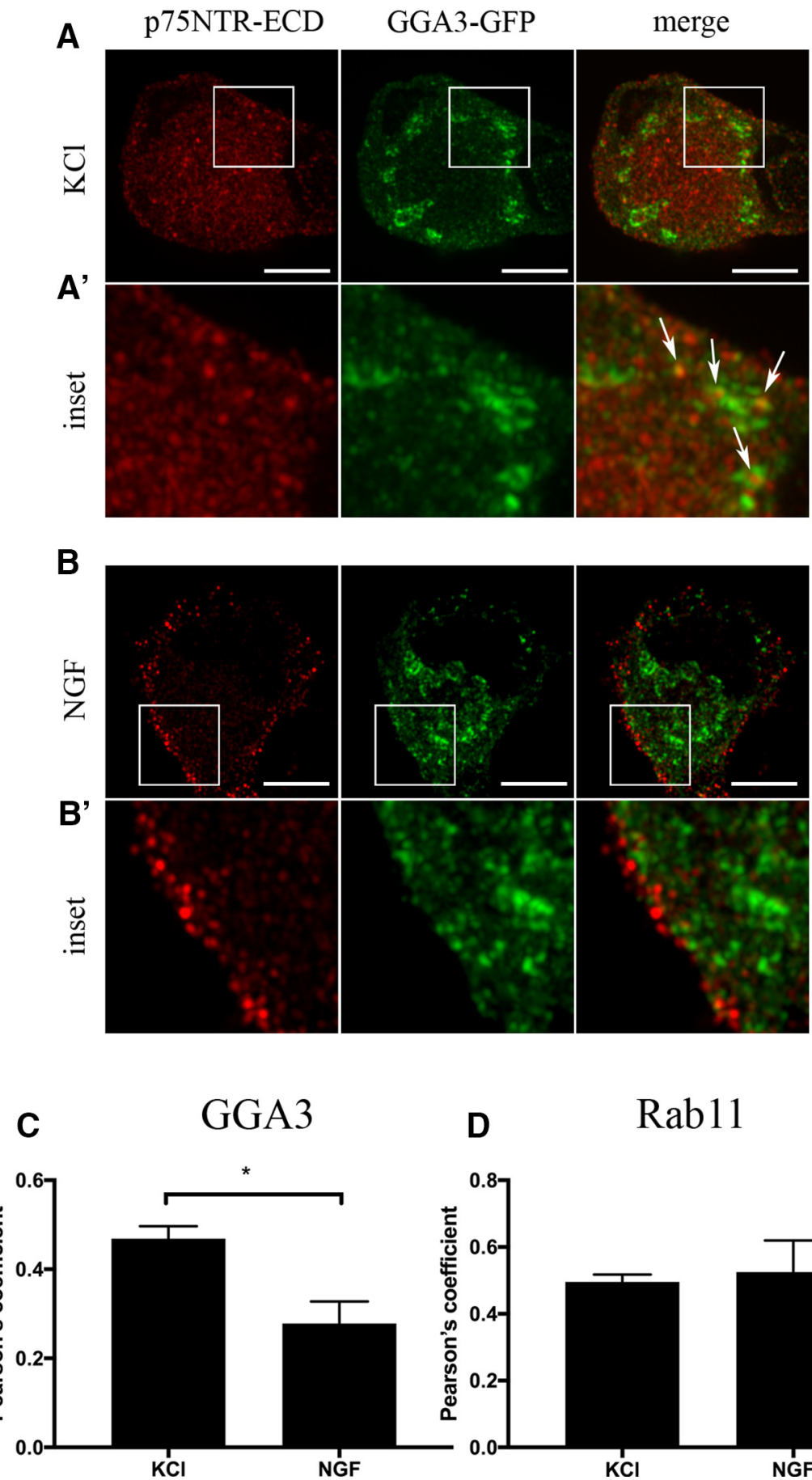

Figure 6. The fraction of intracellular p75NTR colocalized with GGA3 is reduced following NGF treatment. Neurons were electroporated with a plasmid-expressing GGA3 fused to GFP and maintained in KCl for $16 \mathrm{~h}$. Neurons were then either incubated in $40 \mathrm{ng} / \mathrm{ml} \mathrm{NGF}$ for $2 \mathrm{~h}$ or kept in $\mathrm{KCl}(12.5 \mathrm{~mm})$. High-resolution z stacks of GFP ${ }^{+}, \mathrm{NF}^{+}$neurons were acquired using Zeiss $880 \mathrm{LSM}$ with Airyscan $\left(\boldsymbol{A}, \boldsymbol{A}^{\prime}\right)$. Representative images of a neuron maintained in $\mathrm{KCl}$ and showing p75NTR (red) colocalized with internal GGA3-GFP (green). Arrows indicate regions of colocalization adjacent to the membrane (inset). $\boldsymbol{B}, \boldsymbol{B}^{\prime}$, This colocalization decreases upon NGF treatment. While GGA3 puncta are still visible adjacent to the membrane, most p75NTR has translocated to the surface. Graphs represent quantification of Pearson's $r$ coefficient for p75NTR colocalization with GGA3 (C) or Rab11 (D) from each treatment $\left(n=3\right.$ independent experiments). ${ }^{*} p<0.05$. Scale bar, $5 \mu \mathrm{m}$.

sponsiveness is due to the increased availability of p75NTR at the plasma membrane, we repeated this experiment using $p 75 \mathrm{NTR}^{-/-}$ mice. Compared with their wild-type controls, p75NTR knock-out neurons expressing CA Arf6 exhibited significantly longer neurites in response to NT3 (Fig. $7 E ; F_{(3,8)}=7.2, p=0.011$ ). Together, these results indicate that Arf6 activation induces 

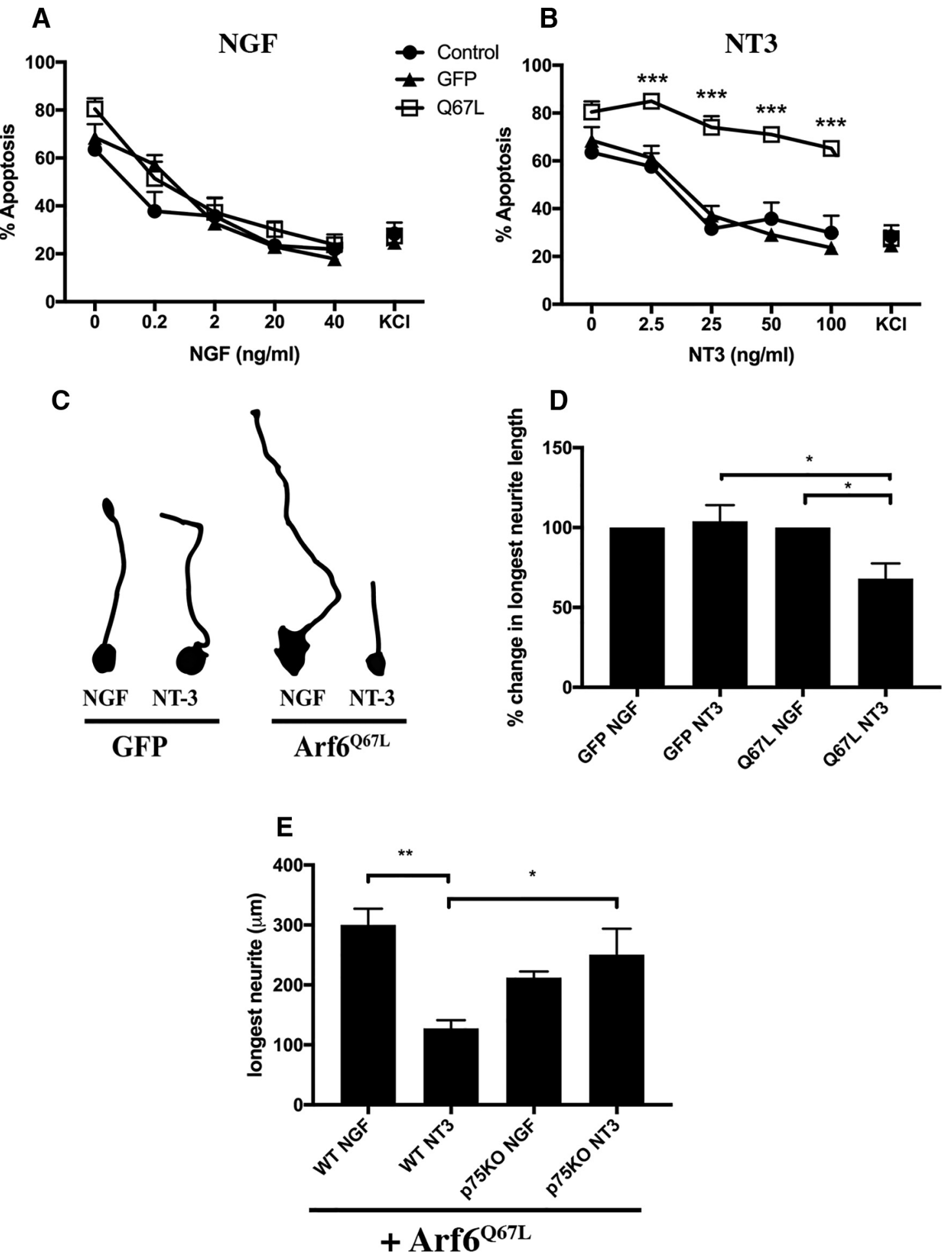

Figure 7. Constitutively active Arf6 alters NT3, but not NGF, mediated survival and neurite outgrowth of sympathetic neurons. Sympathetic neurons were electroporated with a plasmid expressing GFP (triangles) or GFP and Q67L Arf6 (square) or untreated (circle), then cultured with KCl for $2 \mathrm{~d}$. The neurons were then treated with the indicated concentration of ( $\boldsymbol{A}$ ) NGF or ( $\boldsymbol{B}$ ) NT3 or maintained in $\mathrm{KCl}$. After $48 \mathrm{~h}$, the neurons were fixed, immunostained for TuJ1 to mark neurons, and the nuclei labeled with DAPI. The percentage of apoptotic neurons was determined based on the DAPI staining $(n=3) .{ }^{* * *} p \leq 0.01$. Neurite outgrowth was analyzed after $16 \mathrm{~h}$ of neurotrophin treatment, and neurofilament (NF) immunostaining was used to mark neurites. The longest neurite from each GFP ${ }^{+}$cell was measured. C, Representative traces of neurite outgrowth from each condition and (D) quantification of GFP ${ }^{+}$cells in each condition $(n=3$ independent experiments). One-way ANOVA between treatments: ${ }^{*} p<0.05$ (Tukey's multiple comparisons); GFP NT3 versus Q67L NT3: ${ }^{*}<<0.05 ;$ Q Q67L NGF versus Q67L NT3: ${ }^{*} p<0.05$. E, Sympathetic neurons from wild-type or $p 75 \mathrm{NTR}^{-1-}$ mice were electroporated with Q67L Arf and GFP and immediately plated in either NGF or NT3 for $48 \mathrm{~h}$ before fixing. The longest neurite from each GFP ${ }^{+}$, $\mathrm{NF}^{+}$cell was measured ( $n=3$ independent experiments). One-way ANOVA between treatments: ${ }^{*} p<0.05$ (Tukey's multiple comparisons); WT NGF versus WT NT3: ${ }^{* *} p<0.01 ;$ WT NT3 versus p75KO NT3: ${ }^{*} p<0.05$. 


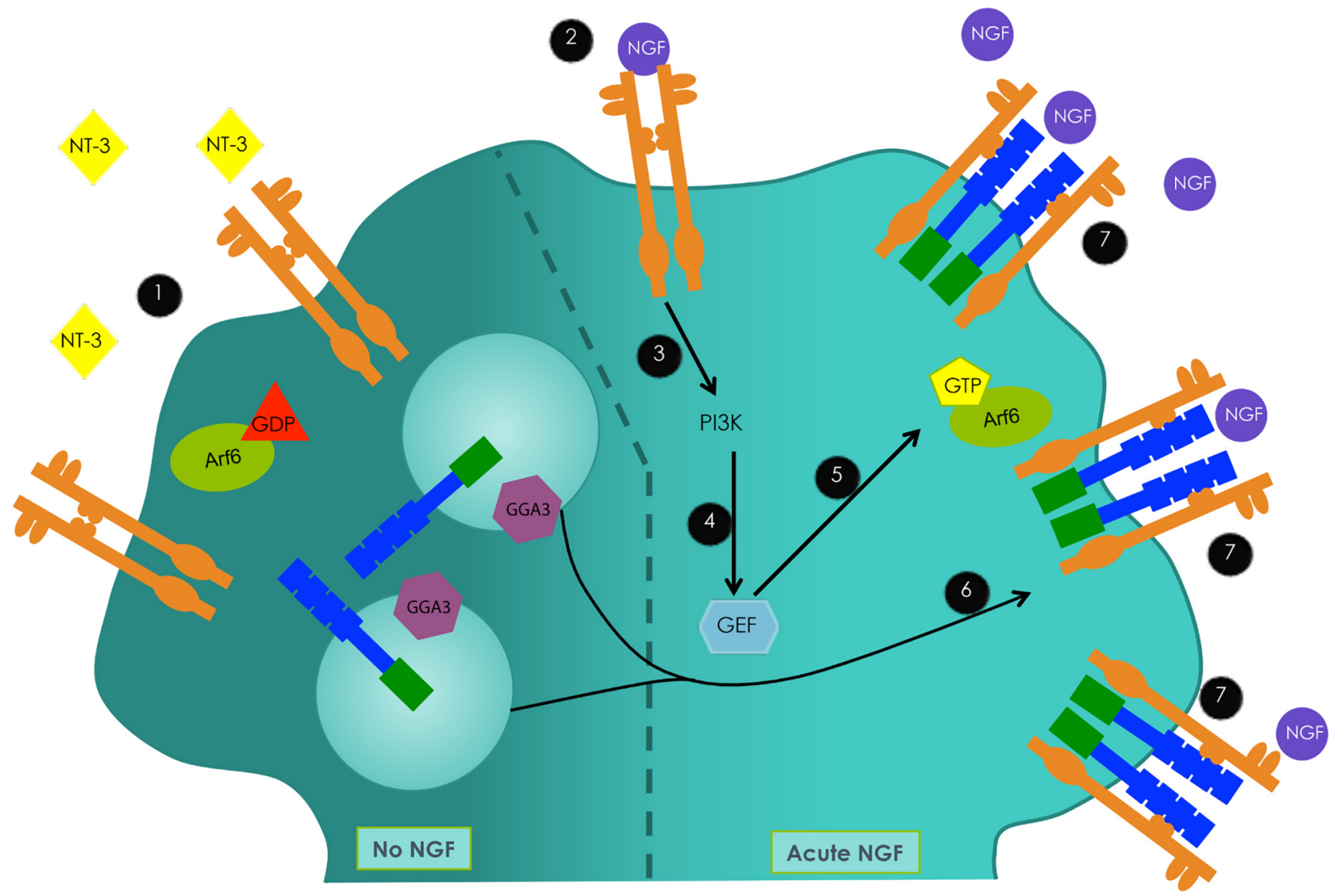

Figure 8. Schematic of rapid NGF regulation of p75NTR trafficking by TrkA activation of Arf6. During axonal growth, sympathetic neurons respond to NT3 through binding to TrkA receptors (1, orange receptors) before reaching NGF-producing target organs. During this time, Arf6 is largely inactive (GDP-bound), and the p75NTR produced is stored in intracellular pools. Once sympathetic axons reach NGF-producing targets, NGF binding to TrkA receptors (2) initiates activation of PI3K (3), which recruits Arf6 GEFs that stimulate GTP binding of Arf6 $(4,5)$. In its active, GTP-bound state, Arf6 initiates transport of p75NTR from GGA3-containing vesicles to the cell surface (6) and promotes the formation of TrkA-p75NTR complexes (7). The high-affinity TrkA-p75 complexes are selective for NGF. NT3 is no longer able to activate TrkA, and sympathetic neurons become dependent on NGF for survival.

upregulation of surface p75NTR, which shifts the responsiveness of the neurons, such that they no longer respond to NT3 (Fig. 8).

\section{Discussion}

During development of the sympathetic nervous system, NGF increases the expression of p75NTR, which is thought to play a key role in shifting the responsiveness of TrkA from NT3 to NGF. However, the mechanisms by which p75NTR expression is regulated and trafficked to the cell surface were not known. In this report, we reveal a novel, rapid, NGF-induced upregulation of surface p75NTR through a TrkA-PI3 kinase-Arf6 pathway in sympathetic neurons. Notably, the acute increase in surface p75NTR following exposure to NGF was from previously existing pools and not the result of newly synthesized receptor, as treatment with CHX did not prevent p75NTR upregulation. Functionally, our results demonstrate that the rapid increase in surface expression of p75NTR shifts the neurotrophic response of sympathetic neurons, blunting the effectiveness of NT3.

Interestingly, this regulatory mechanism was specific for p75NTR, as neither TrkA nor sortilin surface expression was altered under the same conditions. However, Ascaño et al. (2009) reported that TrkA can be rapidly inserted into the growth cones within minutes of NGF treatment. In their study, minimal surface TrkA was detected when NGF was removed and the neurons kept alive by inhibiting caspases. In contrast, we found considerable surface TrkA under neurotrophin naive conditions, when the neurons were maintained in mildly depolarizing conditions with $\mathrm{KCl}$. Therefore, it is possible that depolarization could induce upregulation of TrkA, similar to what has been reported for TrkB (Meyer-Franke et al., 1998; Du et al., 2000), which will be an interesting topic for future studies.

Our study reveals a novel role for Arf6 in regulating the transport of p75NTR to the plasma membrane; however, this GTP binding protein has been shown to modulate the surface presentation of a number of other receptors, often promoting recycling. For example, AMPA receptors were reported to be recycled to the cell surface through Arf6 expressing endosomes (Zheng et al., 2015). Similarly, the internalization and recycling of $\beta 1$ integrin involve Arf6. Notably, in HeLa cells treated with serum (Powelka et al., 2004) or endothelial cells exposed to hepatocyte growth factor (Hongu and Kanaho, 2014), there was an in increase in $\beta 1$ integrin receptor surface expression through Arf6-dependent receptor recycling. Of particular relevance here, Arf6 was recently shown to promote TrkA recycling in PC12 cells treated with NGF through the recruitment of GGA3 (Li et al., 2015). There are 3 GGA family members (GGA1-3), which are adaptor proteins involved in vesicular trafficking in the trans-Golgi network and in endocytosis (Bonifacino, 2004). NGF induced a direct association between TrkA and GGA3, which reduced TrkA degradation and promoted recycling to the cell surface (Li et al., 2015). We did not detect a change in the total surface TrkA expression within $2 \mathrm{~h}$ 
of NGF treatment, suggesting that the existing TrkA at the plasma membrane is efficiently recycled in response to NGF, in agreement with that report. In contrast, the expression of p75NTR at the cell surface was significantly upregulated. This increase in p75NTR at the plasma membrane cannot be explained by receptor recycling because there was minimal expression of $\mathrm{p} 75 \mathrm{NTR}$ at the surface in the absence of NGF. Instead, our results suggest that Arf6 activation promotes the shuttling of p75NTR from preexisting intracellular stores, which (to our knowledge) would be the first example of Arf6 mediating such trafficking.

The upregulation of p75NTR from rapidly accessible storage vesicles appears to occur through a somewhat different mechanism than its neurotrophin-induced recycling. Several groups reported p75NTR internalization via clathrin-dependent and independent mechanisms (Bronfman et al., 2003; Saxena et al., 2004; Deinhardt et al., 2007). Internalization was followed by shuttling through Rab5 ${ }^{+}$early endosomes to Rab7 ${ }^{+}$endosomes for axonal retrograde transport in motor neurons (Deinhardt et al., 2006); and in PC12 cells, p75NTR was recycled via Rab $11^{+}$endosomes or exocytosed from multivesicular bodies (Escudero et al., 2014). However, our data suggest that, although a small fraction of internally stored p75NTR does overlap with $\mathrm{Rab} 11^{+}$vesicles, short-term NGF treatment did not alter this pool of receptor (Fig. $6 D)$. In contrast, we found a portion of internal p75NTR that colocalized with GGA3 in the absence of NGF. Following NGF exposure, much of the colocalization between p75NTR and GGA3 was lost, suggesting that TrkA internalization, which results in GGA3 association (Li et al., 2015), recruits GGA3 from p75NTR-containing vesicles, enabling p75NTR to traffic to the cell surface. Nevertheless, because only a fraction of the internal p75NTR colocalized with GGA3, we cannot rule out the possibility that Arf6 activation also mobilizes p75NTR from additional types of vesicles to the cell surface.

How activation of Arf6 and/or removal of GGA3 would induce transport of p75NTR to the cell surface is not known. Downstream effectors of Arf6 include Rac1, PIP5 kinase, and phospholipase D, which can stimulate PIP5 kinase through production of phosphatidic acid (Jaworski, 2007). Activation of PIP5 kinase results in production of the signaling molecule phosphatidylinositol 4,5bisphosphate, which has been shown to promote plasma membrane association of vesicles containing $\beta 1$-integrin through interaction of phosphatidylinositol 4,5-bisphosphate with components of the exocyst complex (Thapa and Anderson, 2012). Similarly, Arf6-mediated membrane recycling to regions of plasma membrane expansion was reported to involve interaction between Arf6 and the Sec10 component of the exocyst complex (Prigent et al., 2003). It will be of interest to determine whether p75NTR trafficking to the cell surface involves the exocyst complex in future studies.

The increase in p75NTR surface expression and the activation of Arf6 were selective for NGF; NT3 did not have any effect on surface p75NTR upregulation (Fig. 1D) or GTP binding, even at $100 \mathrm{ng} / \mathrm{ml}$ (Fig. 3B). The molecular basis for this selectivity is not known; however, it was previously reported that NGF, but not NT3, is able to induce TrkA internalization (Kuruvilla et al., 2004). The endocytosis of TrkA was shown to occur via NGFselective stimulation phospholipase C, leading to calcineurindependent dynamin 1 activation (Bodmer et al., 2011). In contrast, Harrington et al. (2011) reported that both NGF and NT3 induce TrkA internalization, but in the acidic environment of the endosome, NT3 dissociates while NGF remains bound (Harrington et al., 2011). The postendocytic signaling of NGF resulted in Racl/ cofilin-dependent breakdown of the local actin network, freeing the endosome to be retrogradely transported. Interestingly, Arf6 can also lead to Racl activation (Santy and Casanova, 2001), suggesting that the effects of TrkA on the cytoskeleton may involve Arf6. Nevertheless, both studies demonstrate that NGF mediates internalization and continuous TrkA signaling, whereas NT3 is only able to activate TrkA at the cell surface. Therefore, we suggest that the activation of Arf6 by NGF most likely occurs during or following TrkA internalization.

Our findings indicate that TrkA stimulates Arf6 through a mechanism dependent on PI3 kinase and a member of the cytohesin family of GEFs (Fig. 5). All 8 of the Arf6 GEFs contain a PH domain, which binds to phosphatidylinositol, and the $\mathrm{PH}$ domains of the cytohesins have highest affinity for phosphatidylinositol 3,4,5 triphosphate (Klarlund et al., 1997), a lipid produced by PI3 kinase. Therefore, it is likely that TrkA activation of PI3 kinase induces a local increase in phosphatidylinositol 3,4,5trisphosphate, which recruits a cytohesin, leading to Arf6 activation. In contrast, Li et al. (2015) reported that TrkA activated Arf6 through a mechanism dependent on Src. However, these mechanisms are not mutually exclusive; for example, the Src family member Fyn was reported to phosphorylate cytohesin-1, resulting in activation of the GEF and, subsequently, Arf6 (Yamauchi et al., 2012). Therefore, TrkA may activate Arf6 through PI3 kinasedependent recruitment of a cytohesin, followed by stimulating the cytohesin's GEF activity through Src-mediated phosphorylation.

The ability of NGF to upregulate p75NTR surface expression through the TrkA-Arf6 pathway allows for the critical coordination of sympathetic neuron response to neurotrophins during development. The activation of p75NTR on its own or in association with Vps10p-domain receptor proteins (e.g., sortilin) can induce apoptosis of sympathetic neurons when stimulated by BDNF (Bamji et al., 1998; Palmada et al., 2002) or the proforms of neurotrophins (Nykjaer et al., 2004; Teng et al., 2005). Indeed, p75NTR ${ }^{-1-}$ mice have both an increase in SCG neuron number and a decrease in apoptosis (Bamji et al., 1998; Brennan et al., 1999; Kuruvilla et al., 2004), reflecting the importance of p75NTR's cell death signal during development. The proapoptotic effects of p75NTR have been shown to be critical for balancing the prosurvival effects of TrkA signaling, to establish the proper number of neurons during sympathetic development (Deppmann et al., 2008).

In contrast to its proapoptotic function, p75NTR can also associate with TrkA to form a high-affinity complex for NGF that promotes neuronal survival, differentiation, and neurite growth (Ceni et al., 2014). In the absence of p75NTR, NT3 can bind TrkA and promote axon growth (Benedetti et al., 1993; Belliveau et al., 1997; Kuruvilla et al., 2004), expression of neuronal genes such as tyrosine hydroxylase (Belliveau et al., 1997; Andres et al., 2008), and survival (Davies et al., 1995; Belliveau et al., 1997; Francis et al., 1999). This differential response of TrkA to NT3, regulated by the expression of $\mathrm{p} 75 \mathrm{NTR}$, is critical for proper target innervation during development of the sympathetic nervous system $(\mathrm{Ku}-$ ruvilla et al., 2004). In addition, the upregulation of p75NTR in response to NGF is a very useful mechanism for limiting p75NTRmediated apoptosis in early stages of development. If p75NTR was expressed on the cell surface, as the neurons are growing toward their targets in response to NT3, then NT3 would be restricted from binding TrkA and could, potentially, induce apoptosis through interaction with p75NTR alone.

While we hypothesize that the increase in surface p75NTR expression leads to the formation of high-affinity binding sites, thereby strengthening TrkA survival signaling, an alternate interpretation of the effects of p75NTR upregulation would be that 
p75NTR binds NT3 and acts as a sink to prevent binding to TrkA. However, given that the affinity for NGF and NT3 binding to p75NTR is nearly identical (Dechant et al., 1994) and we only see a change in the responses to NT3 when p75NTR surface expression is increased, not NGF, it is more likely that TrkA is more selective for NGF in the presence of p75NTR.

Given the functional dichotomy of the p75NTR in regulating neuronal survival and apoptosis, a better understanding of the mechanisms that mediate p75NTR surface expression provides key insight not only into the fine-tuning of the developing sympathetic nervous system, but also the aberrant cell death linked to p75NTR in multiple neurodegenerative disorders.

\section{References}

Andres R, Herraez-Baranda LA, Thompson J, Wyatt S, Davies AM (2008) Regulation of sympathetic neuron differentiation by endogenous nerve growth factor and neurotrophin-3. Neurosci Lett 431:241-246. CrossRef Medline

Ascaño M, Richmond A, Borden P, Kuruvilla R (2009) Axonal targeting of trk receptors via transcytosis regulates sensitivity to neurotrophin responses. J Neurosci 29:11674-11685. CrossRef Medline

Bamji SX, Majdan M, Pozniak CD, Belliveau DJ, Aloyz R, Kohn J, Causing CG, Miller FD (1998) The p75 neurotrophin receptor mediates neuronal apoptosis and is essential for naturally occurring sympathetic neuron death. J Cell Biol 140:911-923. CrossRef Medline

Belliveau DJ, Krivko I, Kohn J, Lachance C, Pozniak C, Rusakov D, Kaplan D, Miller FD (1997) NGF and neurotrophin-3 both activate TrkA on sympathetic neurons but differentially regulate survival and neuritogenesis. J Cell Biol 136:375-388. CrossRef Medline

Benedetti M, Levi A, Chao MV (1993) Differential expression of nerve growth factor receptors leads to altered binding affinity and neurotrophin responsiveness. Proc Natl Acad Sci U S A 90:7859-7863. CrossRef Medline

Birren SJ, Lo L, Anderson DJ (1993) Sympathetic neuroblasts undergo a developmental switch in trophic dependence. Development 119:597610. Medline

Bodmer D, Ascaño M, Kuruvilla R (2011) Isoform-specific dephosphorylation of dynamin 1 by calcineurin couples neurotrophin receptor endocytosis to axonal growth. Neuron 70:1085-1099. CrossRef Medline

Bonifacino JS (2004) The GGA proteins: adaptors on the move. Nat Rev Mol Cell Biol 5:23-32. CrossRef Medline

Brennan C, Rivas-Plata K, Landis SC (1999) The p75 neurotrophin receptor influences NT-3 responsiveness of sympathetic neurons in vivo. Nat Neurosci 2:699-705. CrossRef Medline

Bronfman FC, Tcherpakov M, Jovin TM, Fainzilber M (2003) Ligandinduced internalization of the p75 neurotrophin receptor: a slow route to the signaling endosome. J Neurosci 23:3209-3220. CrossRef Medline

Ceni C, Unsain N, Zeinieh MP, Barker PA (2014) Neurotrophins in the regulation of cellular survival and death. Handb Exp Pharmacol 220:193221. CrossRef Medline

Davies AM, Minichiello L, Klein R (1995) Developmental changes in NT3 signalling via TrkA and TrkB in embryonic neurons. EMBO J 14:44824489. Medline

Dechant G, Rodríguez-Tébar A, Barde YA (1994) Neurotrophin receptors. Prog Neurobiol 42:347-352. CrossRef Medline

Deinhardt K, Chao MV (2014) Trk receptors. In: Neurotrophic factors (Lewin GR, Carter BD, eds), pp 103-119. Handbook of experimental pharmacology. Berlin: Springer.

Deinhardt K, Salinas S, Verastegui C, Watson R, Worth D, Hanrahan S, Bucci C, Schiavo G (2006) Rab5 and Rab7 control endocytic sorting along the axonal retrograde transport pathway. Neuron 52:293-305. CrossRef Medline

Deinhardt K, Reversi A, Berninghausen O, Hopkins CR, Schiavo G (2007) Neurotrophins redirect p75NTR from a clathrin-independent to a clathrindependent endocytic pathway coupled to axonal transport. Traffic 8:17361749. CrossRef Medline

Deppmann CD, Mihalas S, Sharma N, Lonze BE, Niebur E, Ginty DD (2008) A model for neuronal competition during development. Science 320: 369-373. CrossRef Medline

D'Souza-Schorey C, Chavrier P (2006) ARF proteins: roles in membrane traffic and beyond. Nat Rev Mol Cell Biol 7:347-358. CrossRef Medline

Du J, Feng L, Yang F, Lu B (2000) Activity- and $\mathrm{Ca}^{2+}$-dependent modula- tion of surface expression of brain-derived neurotrophic factor receptors in hippocampal neurons. J Cell Biol 150:1423-1434. CrossRef Medline

ElShamy WM, Ernfors P (1996) A local action of neurotrophin-3 prevents the death of proliferating sensory neuron precursor cells. Neuron 16:963972. CrossRef Medline

Escudero CA, Lazo OM, Galleguillos C, Parraguez JI, Lopez-Verrilli MA, Cabeza C, Leon L, Saeed U, Retamal C, Gonzalez A, Marzolo MP, Carter BD, Court FA, Bronfman FC (2014) The p75 neurotrophin receptor evades the endolysosomal route in neuronal cells, favouring multivesicular bodies specialised for exosomal release. J Cell Sci 127:1966-1979. CrossRef Medline

Francis N, Farinas I, Brennan C, Rivas-Plata K, Backus C, Reichardt L, Landis S (1999) NT-3, like NGF, is required for survival of sympathetic neurons, but not their precursors. Dev Biol 210:411-427. CrossRef Medline

Furman C, Short SM, Subramanian RR, Zetter BR, Roberts TM (2002) DEF-1/ASAP1 is a GTPase-activating protein (GAP) for ARF1 that enhances cell motility through a GAP-dependent mechanism. J Biol Chem 277:7962-7969. CrossRef Medline

Harrington AW, St Hillaire C, Zweifel LS, Glebova NO, Philippidou P, Halegoua S, Ginty DD (2011) Recruitment of actin modifiers to TrkA endosomes governs retrograde NGF signaling and survival. Cell 146:421-434. CrossRef Medline

Hempstead BL, Martin-Zanca D, Kaplan DR, Parada LF, Chao MV (1991) High-affinity NGF binding requires coexpression of the trk proto-oncogene and the low-affinity NGF receptor. Nature 350:678-683. CrossRef Medline

Hongu T, Kanaho Y (2014) Activation machinery of the small GTPase Arf6. Adv Biol Regul 54:59-66. CrossRef Medline

Hongu T, Funakoshi Y, Fukuhara S, Suzuki T, Sakimoto S, Takakura N, Ema M, Takahashi S, Itoh S, Kato M, Hasegawa H, Mochizuki N, Kanaho Y (2015) Arf6 regulates tumour angiogenesis and growth through HGFinduced endothelial $\beta 1$ integrin recycling. Nat Commun 6:7925. CrossRef Medline

Hutagalung AH, Novick PJ (2011) Role of rab GTPases in membrane traffic and cell physiology. Physiol Rev 91:119-149. CrossRef Medline

Jackson TR, Brown FD, Nie Z, Miura K, Foroni L, Sun J, Hsu VW, Donaldson JG, Randazzo PA (2000) ACAPs are arf6 GTPase-activating proteins that function in the cell periphery. J Cell Biol 151:627-638. CrossRef Medline

Jaworski J (2007) ARF6 in the nervous system. Eur J Cell Biol 86:513-524. CrossRef Medline

Kenchappa RS, Tep C, Korade Z, Urra S, Bronfman FC, Yoon SO, Carter BD (2010) p75 neurotrophin receptor-mediated apoptosis in sympathetic neurons involves a biphasic activation of JNK and up-regulation of tumor necrosis factor- $\alpha$-converting enzyme/ADAM17. J Biol Chem 285:20358 20368. CrossRef Medline

Klarlund JK, Guilherme A, Holik JJ, Virbasius JV, Chawla A, Czech MP (1997) Signaling by phosphoinositide-3,4,5-trisphosphate through proteins containing pleckstrin and Sec7 homology domains. Science 275: 1927-1930. CrossRef Medline

Kraemer BR, Yoon SO, Carter BD (2014) The biological functions and signaling mechanisms of the p75 neurotrophin receptor. In: Neurotrophic factors (Lewin GR, Carter BD, eds), pp 121-164. Handbook of experimental pharmacology. Berlin: Springer.

Kuruvilla R, Zweifel LS, Glebova NO, Lonze BE, Valdez G, Ye H, Ginty DD (2004) A neurotrophin signaling cascade coordinates sympathetic neuron development through differential control of TrkA trafficking and retrograde signaling. Cell 118:243-255. CrossRef Medline

Lee KF, Davies AM, Jaenisch R (1994) p75-deficient embryonic dorsal root sensory and neonatal sympathetic neurons display a decreased sensitivity to NGF. Development 120:1027-1033. Medline

Li X, Lavigne P, Lavoie C (2015) GGA3 mediates TrkA endocytic recycling to promote sustained Akt phosphorylation and cell survival. Mol Biol Cell 26:4412-4426. CrossRef Medline

Meyer-Franke A, Wilkinson GA, Kruttgen A, Hu M, Munro E, Hanson MG Jr, Reichardt LF, Barres BA (1998) Depolarization and cAMP elevation rapidly recruit TrkB to the plasma membrane of CNS neurons. Neuron 21:681-693. CrossRef Medline

Miller FD, Speelman A, Mathew TC, Fabian J, Chang E, Pozniak C, Toma JG (1994) Nerve growth factor derived from terminals selectively increases the ratio of $\mathrm{p} 75$ to trkA NGF receptors on mature sympathetic neurons. Dev Biol 161:206-217. CrossRef Medline

Nykjaer A, Lee R, Teng KK, Jansen P, Madsen P, Nielsen MS, Jacobsen C, 
Kliemannel M, Schwarz E, Willnow TE, Hempstead BL, Petersen CM (2004) Sortilin is essential for proNGF-induced neuronal cell death. Nature 427:843-848. CrossRef Medline

Palmada M, Kanwal S, Rutkoski NJ, Gustafson-Brown C, Johnson RS, Wisdom R, Carter BD, Gufstafson-Brown C (2002) c-jun is essential for sympathetic neuronal death induced by NGF withdrawal but not by p75 activation. J Cell Biol 158:453-461. CrossRef Medline

Powelka AM, Sun J, Li J, Gao M, Shaw LM, Sonnenberg A, Hsu VW (2004) Stimulation-dependent recycling of integrin betal regulated by ARF6 and Rab11. Traffic 5:20-36. CrossRef Medline

Prigent M, Dubois T, Raposo G, Derrien V, Tenza D, Rossé C, Camonis J, Chavrier P (2003) ARF6 controls post-endocytic recycling through its downstream exocyst complex effector. J Cell Biol 163:1111-1121. CrossRef Medline

Santy LC, Casanova JE (2001) Activation of ARF6 by ARNO stimulates epithelial cell migration through downstream activation of both Rac1 and phospholipase D. J Cell Biol 154:599-610. CrossRef Medline

Saxena S, Howe CL, Cosgaya JM, Hu M, Weis J, Krüttgen A (2004) Differences in the surface binding and endocytosis of neurotrophins by p75NTR. Mol Cell Neurosci 26:292-307. CrossRef Medline

Schindelin J, Arganda-Carreras I, Frise E, Kaynig V, Longair M, Pietzsch T, Preibisch S, Rueden C, Saalfeld S, Schmid B, Tinevez JY, White DJ, Hartenstein V, Eliceiri K, Tomancak P, Cardona A (2012) Fiji: an opensource platform for biological-image analysis. Nat Methods 9:676-682. CrossRef Medline

Teng HK, Teng KK, Lee R, Wright S, Tevar S, Almeida RD, Kermani P, Torkin R, Chen ZY, Lee FS, Kraemer RT, Nykjaer A, Hempstead BL (2005) ProBDNF induces neuronal apoptosis via activation of a receptor complex of p75NTR and sortilin. J Neurosci 25:5455-5463. CrossRef Medline
Thapa N, Anderson RA (2012) PIP2 signaling, an integrator of cell polarity and vesicle trafficking in directionally migrating cells. Cell Adhes Migr 6:409-412. CrossRef Medline

Venkateswarlu K, Gunn-Moore F, Tavaré JM, Cullen PJ (1999) EGF- and NGF-stimulated translocation of cytohesin-1 to the plasma membrane of PC12 cells requires PI 3-kinase activation and a functional cytohesin-1 PH domain. J Cell Sci 112:1957-1965. Medline

Verdi JM, Anderson DJ (1994) Neurotrophins regulate sequential changes in neurotrophin receptor expression by sympathetic neuroblasts. Neuron 13:1359-1372. CrossRef Medline

Volpicelli-Daley LA, Li Y, Zhang CJ, Kahn RA (2005) Isoform-selective effects of the depletion of ADP-ribosylation factors 1-5 on membrane traffic. Mol Biol Cell 16:4495-4508. CrossRef Medline

Wieland F, Harter C (1999) Mechanisms of vesicle formation: insights from the COP system. Curr Opin Cell Biol 11:440-446. CrossRef Medline

Wyatt S, Davies AM (1995) Regulation of nerve growth factor receptor gene expression in sympathetic neurons during development. J Cell Biol 130: 1435-1446. CrossRef Medline

Yamauchi J, Miyamoto Y, Torii T, Takashima S, Kondo K, Kawahara K, Nemoto N, Chan JR, Tsujimoto G, Tanoue A (2012) Phosphorylation of cytohesin- 1 by Fyn is required for initiation of myelination and the extent of myelination during development. Sci Signal 5:ra69. CrossRef Medline

Zerial M, McBride H (2001) Rab proteins as membrane organizers. Nat Rev Mol Cell Biol 2:107-117. CrossRef Medline

Zheng N, Jeyifous O, Munro C, Montgomery JM, Green WN (2015) Synaptic activity regulates AMPA receptor trafficking through different recycling pathways. eLife 4:06878. CrossRef Medline 